\title{
A seasonal study of diatom dynamics in the North Atlantic during the POMME experiment (2001): Evidence for Si limitation of the spring bloom
}

\author{
K. Leblanc, ${ }^{1,2}$ A. Leynaert, ${ }^{3}$ C. Fernandez I., ${ }^{1}$ P. Rimmelin, ${ }^{1}$ T. Moutin, ${ }^{1}$ P. Raimbault, ${ }^{1}$ \\ J. Ras, ${ }^{4}$ and B. Quéguiner ${ }^{1}$
}

Received 24 July 2004; revised 11 January 2005; accepted 3 February 2005; published 8 July 2005.

[1] The Si cycle in the northeast Atlantic $\left(40^{\circ}-43.5^{\circ} \mathrm{N}, 15^{\circ}-21^{\circ} \mathrm{W}\right)$ was investigated in the winter, spring, and late summer during the Programme Océan Multidisciplinaire Méso Echelle (POMME) (2001). The aim of this study was to determine the principal causes of the onset and subsequent decline of the diatom bloom, with an emphasis on nutritional limitation processes. The siliceous compartment dynamics was characterized through silicic acid distribution, size-fractionated biogenic silica and Si uptake rates, Si uptake kinetics $\left(K_{S}\right.$ and $\left.V_{\max }\right)$, and export rates. The results of the POMME cruises indicated an important seasonal variability of the siliceous compartment in the North Atlantic together with a spatial variability following a south-north gradient in parallel to the increasing stock of nutrients. Here we present the first kinetic evidences for Si limitation of the diatom spring bloom in the northeast Atlantic, supporting previous reports of potentially limiting silicic acid concentrations in this region. Integrated Si uptake rates were very low throughout the survey, except at the northern anticyclonic eddy site, where a Pseudo-nitzschia bloom was observed during spring and ranged between 0.04 and $11.2 \mathrm{mmol} \mathrm{m}^{-2} \mathrm{~d}^{-1}$, which is comparable to values obtained in oligotrophic regions. The overall annual Si production budget for the entire POMME area $\left(375,000 \mathrm{~km}^{2}\right)$ was

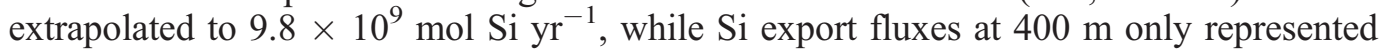
$3 \%$ of the surface production.

Citation: Leblanc, K., A. Leynaert, C. Fernandez I., P. Rimmelin, T. Moutin, P. Raimbault, J. Ras, and B. Quéguiner (2005), A seasonal study of diatom dynamics in the North Atlantic during the POMME experiment (2001): Evidence for Si limitation of the spring bloom, J. Geophys. Res., 110, C07S14, doi:10.1029/2004JC002621.

\section{Introduction}

[2] The intense spring bloom occurring each year in the North Atlantic is often depicted as the most important biological signal visible from space [Esaias et al., 1986]. The combined effect of the $\mathrm{CO}_{2}$ solubility pump and the biological pump confers to this oceanic area the status of a large $\mathrm{CO}_{2}$ sink, which was estimated to range from 6 to $8 \times$ $10^{12} \mathrm{gC} \mathrm{yr}^{-1}$ [Takahashi et al., 2002]. In the eastern North Atlantic, the winter mixed layer depth discontinuity zone divides the basin into two regions: north of this discontinuity, the bloom is thought to progress northward following the onset of the spring stratification as described in Sverdrup's critical depth model [Sverdrup, 1953]; south of this

\footnotetext{
${ }^{1}$ Laboratoire d'Océanographie et de Biogéochimie, UMR 6535, CNRS, Université de la Méditerranée, Campus de Luminy, Marseille, France.

${ }^{2}$ Currently at College of Marine Studies, Lewes, Delaware, USA.

${ }^{3}$ Laboratoire "Flux de matière et réponse du vivant," Institut Universitaire Européen de la Mer, Technopôle Brest-Iroise, Plouzané, France.

${ }^{4}$ Laboratoire d'Océanographie de Villefranche, CNRS-INSU et Université Pierre et Marie Curie, Villefranche-sur-mer, France.

Copyright 2005 by the American Geophysical Union. 0148-0227/05/2004JC002621
}

boundary, the shallower winter mixing brings less nutrients to surface waters, making this more oligotrophic region more likely to be nutrient than light-limited [Siegel et al., 2001]. The south-north density gradient is furthermore disrupted by a large mesoscale activity in this region, generating eddies generally less than $100 \mathrm{~km}$ wide, which induces a secondary spatial variability of nutrient stocks. Hence the northward progression of the spring bloom is not homogeneous but has rather been depicted as a moving patchwork of mesoscale features characterized by different bloom stages [Karrasch et al., 1996].

[3] The North Atlantic spring bloom is usually dominated by diatoms supporting pulse-like sedimentation events [Lampitt, 1985; Berger and Wefer, 1990; Lampitt and Antia, 1997], which are thought to contribute for a large part to the export of organic carbon to the deep ocean [Smetacek, 1985; Honjo and Manganini, 1993]. Diatoms distinguish themselves from other phytoplanktonic groups by their absolute requirement for dissolved $\mathrm{Si}$, necessary to their metabolism and cell wall formation [Sullivan and Volcani, 1981]. A lot of interest is usually given to the role of nitrogen in the progression of the spring bloom, while relatively fewer studies focus on the role of silicon, which is necessary to diatom growth. Silicic acid depletion has been reported as the 

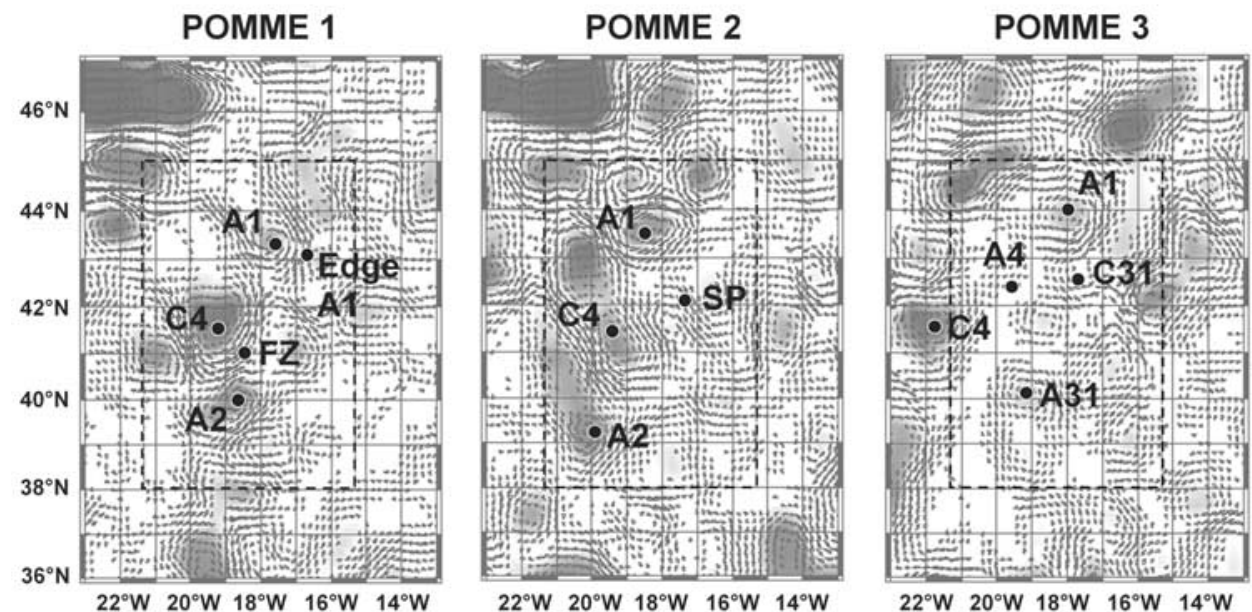

Figure 1. Synoptic current maps at $100 \mathrm{~m}$ for the second legs were derived from the SOPRANE model (M. Assenbaum, LEGOS/CNRS). Cyclonic and anticyclonic eddies were positioned and numbered (C, cyclonic; A, anticyclonic). The study sites (black dots) sampled during the second legs were repositioned according to the hydrological features.

principal cause for the decline of the spring bloom in several hydrological regimes including the North Atlantic [Lochte et al., 1993; Sieracki et al., 1993]. However, this oceanic region remains largely undersampled with regards to silicic acid distribution [Louanchi and Najjar, 2001] and estimates of Si uptake rates are scarce. In the North Atlantic, Si production rates were quantified in the western Atlantic mid-ocean gyres [Brzezinzki and Nelson, 1989, 1996; Brzezinski and Kosman, 1997], in a coastal African upwelling [Nelson and Goering, 1978] and more recently in the northeast Atlantic between Iceland and Scotland [Brown et al., 2003].

[4] In this article, we present a comprehensive study of the Si cycle dynamics in several mesoscale structures of the eastern Atlantic during a winter-summer transition survey. The Programme Océan Multidisciplinaire Méso Echelle (POMME) study area was located between the Azores Island and the Iberian peninsula, encompassing a region characterized by strong mesoscale activity as well as by a meridional gradient located at $41^{\circ}-41.5^{\circ} \mathrm{N}$, where an eastward current extended through the POMME domain [Giordani et al., 2005; Mémery et al., 2005].

[5] The aim of this study was to determine the principal cause of the onset and subsequent decline of the diatom bloom, with an emphasis on nutritional limitation processes. The diatom bloom progression was investigated during winter, spring and late summer 2001 in the $38^{\circ}-45^{\circ} \mathrm{N}$, $15^{\circ}-21^{\circ} \mathrm{W}$ area at several $1-\mathrm{D}$ study sites. The siliceous compartment dynamics was characterized through silicic acid distribution, size-fractionated biogenic silica and $\mathrm{Si}$ uptake rates, $\mathrm{Si}$ uptake kinetics $\left(K_{S}\right.$ and $\left.V_{\max }\right)$ and $\mathrm{Si}$ export rates. Here, we present the first kinetic evidences for $\mathrm{Si}$ limitation of the diatom spring bloom in the northeast Atlantic, supporting previous reports of potentially limiting silicic acid concentrations in this region.

\section{Methods}

\subsection{Study Area and Sampling Strategy}

[6] The POMME program was conducted in the northeast Atlantic on board R/V L'Atalante and Thalassa (IFREMER) in 2001. The three POMME cruises (P1, P2, P3) were each divided into two legs covering the winter, spring and late summer seasons. The first legs were dedicated to an extensive coverage of the study area while the second legs were aimed at performing process studies within specific hydrological features. Mesoscale structures such as cyclonic or anticyclonic eddies, and frontal areas were resolved by combining data from floats and drifters deployed into the area (Marvors, Provors and Surdrifts), CTD and XBT data obtained during the first legs, as well as altimetric sea level measurements (see details of Mémery et al. [2005]). Data assimilation and modeling using the SOPRANE model [Assenbaum and Reverdin, 2005] yielded synoptic current maps and allowed to accurately relocate each study site on its corresponding hydrological feature (Figure 1). This study presents the data acquired during the second legs for different mesoscale features (Table 1), some of which were transient while others could be followed throughout the year such as: a northern anticyclonic eddy identified as A1, a cyclonic eddy identified as C4 and a southern anticyclonic eddy identified as A2. This last structure unfortunately drifted out of the study area during P3 and was replaced by a smaller anticyclonic eddy at the same latitude, A31. A general drift of most eddies toward the southwest was noticeable between the cruises [Le Cann et al., 2005].

[7] Each study site was sampled during 3 days. Arriving on site, a drifting line equipped with two sediment traps (200 and $400 \mathrm{~m}$ ) was immerged for a 48 hour period. On the first day, particulate and dissolved silica were sampled with a rosette sampler on a deep CTD cast $(0-1000 \mathrm{~m})$. On the second day, the $0-100 \mathrm{~m}$ layer was sampled before dawn for the same parameters, and supplementary whole water samples for silicic acid uptake measurements were attached to a drifting line at the depth of collection and incubated in situ for 24 hours.

\subsection{Dissolved and Particulate Matter}

[8] Major nutrient measurements $\left(\mathrm{NO}_{3}^{-}, \mathrm{PO}_{4}^{3-}\right)$ were performed at every station and prior to the tracer incubation 
Table 1. Conductivity-Temperature-Depth (CTD) Casts Coordinates and Hydrological Characteristics of the Study Sites During the Second Legs of the Three Programme Océan Multidisciplinaire Méso Echelle (POMME) Cruises (P1, P2, P3) ${ }^{\mathrm{a}}$

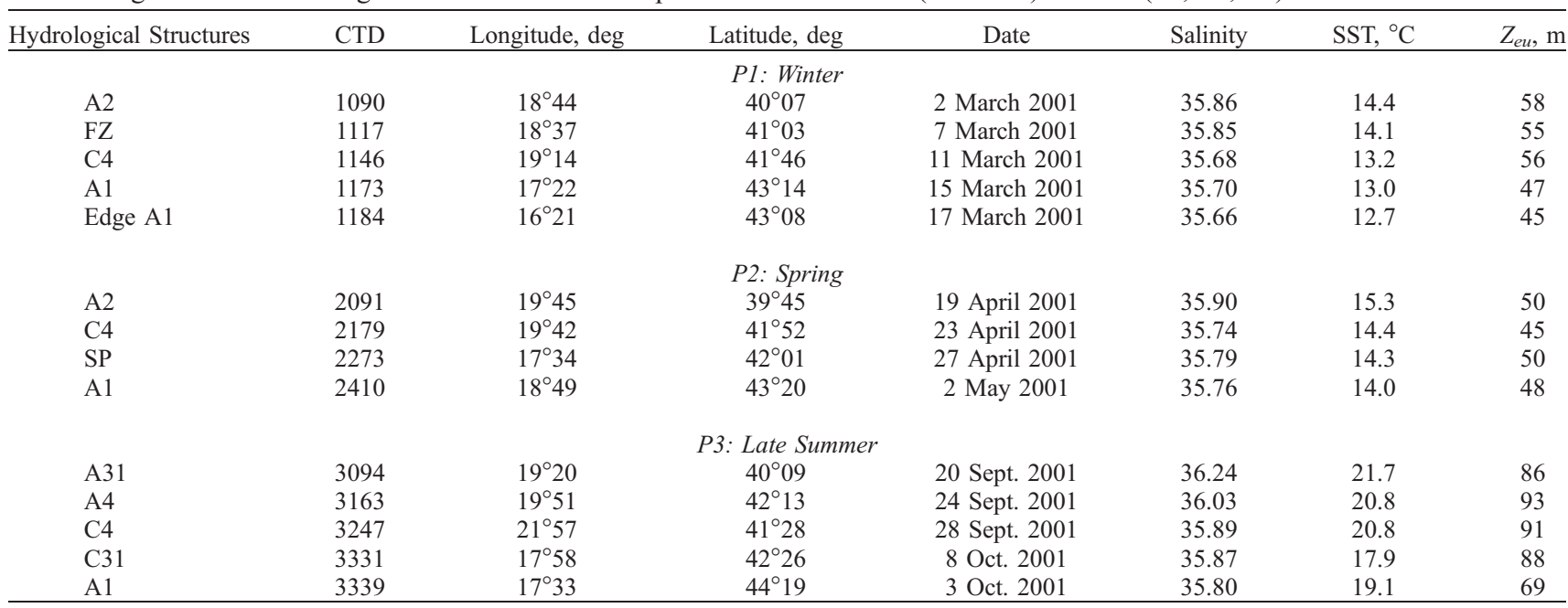

${ }^{\mathrm{a}}$ The mesoscale structures that were sampled are defined by letters (A, anticyclonic eddy; C, cyclonic eddy) and by numbers for each new eddy. Apart from eddies, a frontal zone (FZ) and an area of no eddy activity (SP, Saddle Point) were also sampled. SST, sea surface temperature; $Z_{\text {eu }}$, surface salinities and the depths of the euphotic zone.

experiments. Samples were taken before dawn in a $20 \mathrm{~mL}$ polyethylene flask. All samples were analyzed on board immediately after sampling according to Tréguer and Le Corre [1975], using a Technicon Autonanalyser ${ }^{\circledR}$. The detection limits are $0.05 \mu \mathrm{M}$ and $0.02 \mu \mathrm{M}$ for nitrate and phoshate respectively. Silicic acid samples were preserved with $25 \mu \mathrm{L}$ mercuric chloride $\left(\mathrm{HgCl}_{2}\right)$ and stored at $4^{\circ} \mathrm{C}$ until analysis at the laboratory. Dissolved silicon was measured manually on a spectrophotometer following Brzezinski and Nelson [1986] on a CECIL spectrofluorometer, with a detection limit of $0.05 \mu \mathrm{M}$.

[9] Pigment samples were filtered onto $0.7 \mu \mathrm{m}$ filters (Whatman GF/F, $25 \mathrm{~mm}$ ) and stored in liquid nitrogen until analysis. Samples were extracted in $3 \mathrm{~mL}$ HPLCgrade methanol and injected onto a reversed phase $\mathrm{C} 8$ Hypersil MOS column (dimensions: $3 \times 100 \mathrm{~mm}, 3 \mu \mathrm{m}$ pore size) and analyzed with an Agilent Technologies 1100 series HPLC system coupled with a Thermoquest AS3000 autosampler according to the protocol described by Claustre et al. [2004]. Precision of the method averaged 5\% and detection limits for $\mathrm{TChl}$ a and fucoxanthin (a pigment found in diatoms) were above $0.001 \mathrm{mg} \mathrm{m}^{-3}$.

[10] Particulate biogenic silica (BSi) samples were filtered on cascading filter towers onto $0.6 \mu \mathrm{m}$ and $10 \mu \mathrm{m}$ filters (Nucleopore, $47 \mathrm{~mm}$ ) allowing size fractionation. Filters were dried at room temperature on board and assayed for biogenic silica following the hot $\mathrm{NaOH}$ digestion technique described by Nelson et al. [1989]. $B$ Si trap samples were measured following the same method and the final Si flux was corrected for the initial input of silicic acid in the cup with the formaldehyde solution and for $B \mathrm{Si}$ dissolution after collection within each cup. Immediately after sample filtration for $B \mathrm{Si}$ assays, the concentration of dissolved silicic acid remaining in the filtrate was measured. These values were corrected for the initial amount of dissolved $\mathrm{Si}$ present in the filtered seawater used to fill the sampling cups and then added to the particulate $B S i$ values to correct for dissolution of diatom frustules after collection.

\subsection{Si Uptake Rate Profiles and Kinetic Parameters}

[11] Dawn-to-dawn (24 hours) in situ uptake experiments were realized using an immersed production line at eight incubation depths chosen over the $0-100 \mathrm{~m}$ layer. Whole seawater samples $(275 \mathrm{~mL})$ were collected before dawn and spiked with $0.022 \mu \mathrm{Ci}(800 \mathrm{~Bq})$ of the radioactive isotope silicon-32 $\left({ }^{32} \mathrm{Si}\right)$, which specific activity was $15.6 \mathrm{kBq} \mu \mathrm{g}$ $\mathrm{Si}^{-1}$. After incubation, samples were filtered on cascading filter towers onto $0.6 \mu \mathrm{m}$ and $10 \mu \mathrm{m}$ filters (Nucleopore, $47 \mathrm{~mm}$ ) allowing size fractionation. Filters were rinsed with filtered $(0.2 \mu \mathrm{m})$ seawater, and placed in scintillation vials. The ${ }^{32} \mathrm{Si}$ uptake was measured in a Packard 1600-TR scintillation counter by Cerenkov effect, following the method described by Tréguer et al. [1991] and Leynaert [1993]. Precision of the method averages $10 \%$. Si specific uptake rates $V \mathrm{Si}$ (in $\mathrm{d}^{-1}$ ) have been derived from $B \mathrm{Si}$ (in $\mu \mathrm{mol} \mathrm{L}{ }^{-1}$ ) and $\rho \mathrm{Si}$ (absolute Si uptake rates in $\mu \mathrm{mol} \mathrm{L} \mathrm{L}^{-1}$ $\mathrm{d}^{-1}$ ) measurements using the following equation:

$$
V \mathrm{Si}=\frac{\rho \mathrm{Si}}{B \mathrm{Si}}
$$

[12] Kinetic uptake experiments were carried out at 20 and $40 \mathrm{~m}$ at all sites except during P3. The water samples were collected from the same Niskin bottles as those used for in situ incubation. Samples were spiked with ${ }^{32} \mathrm{Si}$ and received increasing $\mathrm{Na}_{2} \mathrm{SiO}_{3}$ additions ranging from 0.5 to $50 \mu \mathrm{M}$. Bottles were incubated on deck for 8 hours in flowthrough incubators maintained at sea surface temperature and covered with nickel screens $(22.5$ and $8 \%$ of incident irradiance). Samples were thereafter treated as described for in situ samples. Kinetic parameters $V_{\max }$ and $K_{S}$ were calculated by fitting the data to a Michaelis-Menten curve using Sigmaplot ${ }^{\mathrm{R}}$. 
A2
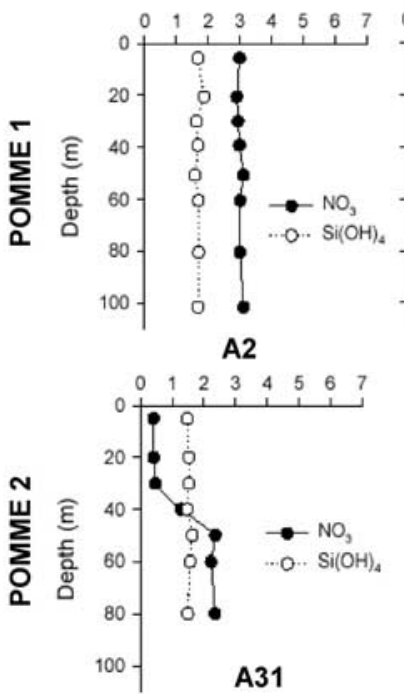

$\begin{array}{llllllll}0 & 1 & 2 & 3 & 4 & 5 & 6 & 7\end{array}$
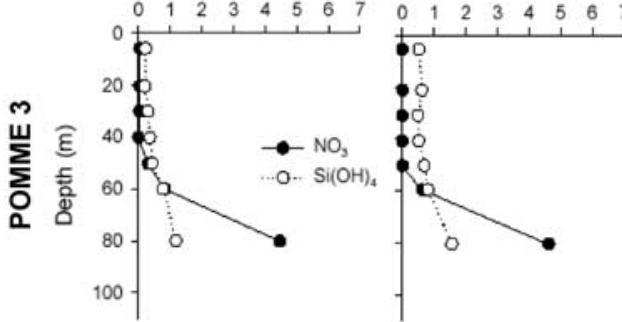

FZ
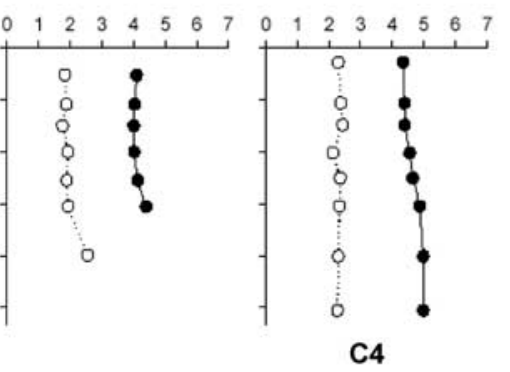

C4

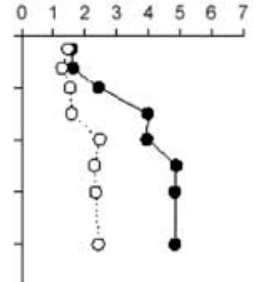

C4

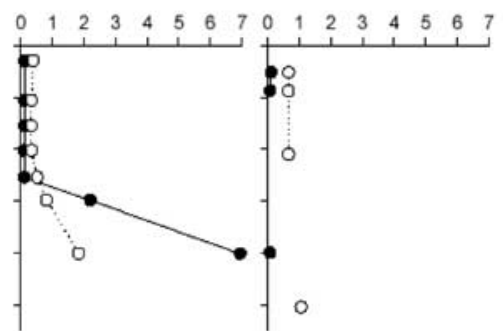

Edge A1

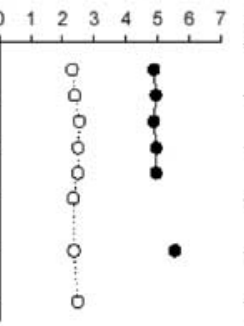

SP

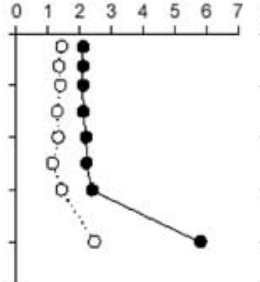

C31

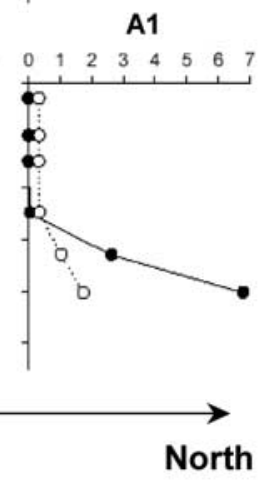

A1

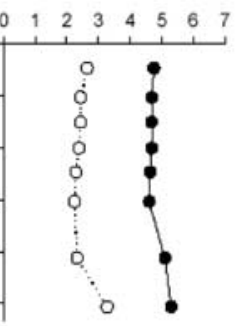

A1

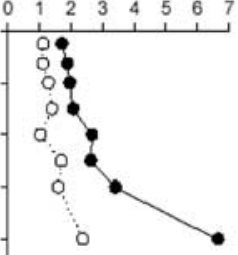

A1

Figure 2. Vertical silicic acid and nitrate profiles $(\mu \mathrm{M})$ for the $0-100 \mathrm{~m}$ layer during the three cruises POMME 1, 2, and 3.

\subsection{Primary Production}

[13] Primary production (PP) rates and integrated primary production ( $\Sigma \mathrm{PP})$ were measured in situ using the ${ }^{14} \mathrm{C}$ method according to Moutin and Raimbault [2002]. No PAR (Photosynthetically Active Radiation) profiles were available for the POMME cruises, but the depth of the euphotic zone was derived from the integrated Chl $a$ content of the water column according to Morel and Berthon [1989].

\section{Results}

\subsection{Hydrological Features}

[14] The water mass composed between the surface and the permanent deep thermocline (500-800 m) was entirely constituted of the Eastern North Atlantic Central Water (ENACW), identified by salinities $>35.5$. The ENACW are also characterized by temperatures $>10^{\circ} \mathrm{C}$ and rising to values ranging from $13^{\circ}$ to $22^{\circ} \mathrm{C}$ in the late summer [van Aken, 2001]. The study area was characterized by the presence of several mesoscale cyclonic and anticyclonic eddies as well as by an eastward current located at $41^{\circ}-$ $41.5^{\circ} \mathrm{N}$. This current, characterized by an intense isopycnal displacement, was a quasi-permanent structure at least until June 2001, but presented at individual times large meanders around various eddy structures [Mémery et al., 2005].
[15] A full hydrographic description of these structures is given in companion papers [Le Cann et al., 2005; Giordani et al., 2005; Reverdin et al., 2005; Fernández et al., 2005] and is beyond the scope of this paper. For each study site, the sea surface temperatures (SST), the surface salinities and the depths of the euphotic zone $\left(Z_{e u}\right)$ are reported in Table 1. In March, surface temperatures ranged from $12.7^{\circ}$ to $14.4^{\circ} \mathrm{C}$, increased by approximately $1^{\circ} \mathrm{C}$ during spring season and increased further by approximately $6^{\circ} \mathrm{C}$ in the late summer. $Z_{e u}$ values were intermediate during winter $(45-58 \mathrm{~m})$, decreased slightly during spring bloom (45$50 \mathrm{~m}$ ) except at the anticyclone A1 site where it remained equivalent, and increased during the oligotrophic late summer period $(69-91 \mathrm{~m})$.

\subsection{Nutrient Stocks}

[16] Nitrate and silicic acid profiles in the $0-100 \mathrm{~m}$ layer for each site are presented in Figure 2. In the winter (P1), silicic acid concentrations ranged from 1.6 to $2.5 \mu \mathrm{M}$ and were always lower than nitrate concentrations, with an average difference of $1.5-2 \mu \mathrm{M}$. Both surface nitrate and silicic acid availability were lowest in the south and increased progressively to the north. In the spring (P2), nutrients decreased significantly but were not completely depleted. Nitrate concentrations remained below $2 \mu \mathrm{M}$ and silicic acid concentrations ranged from 1 to $1.5 \mu \mathrm{M}$. Silicic acid levels 

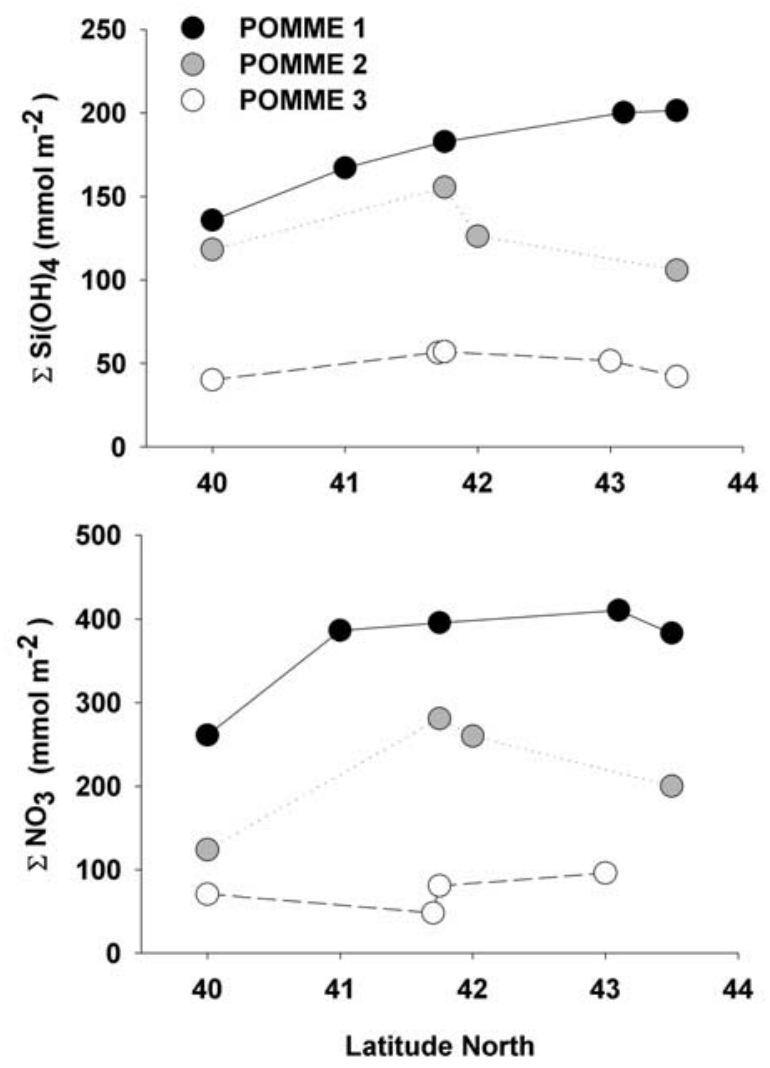

Figure 3. Integrated silicic acid and nitrate stocks along the south-north gradient $\left(40^{\circ}-44^{\circ} \mathrm{N}\right)$ in $\mathrm{mmol} \mathrm{m} \mathrm{m}^{-2}$.

were again lower than nitrate except at anticyclone A2, where nitrate was on average $0.5 \mu \mathrm{M}$ in the first $30 \mathrm{~m}$. In the late summer (P3), nutrients were severely depleted over the first 50-60 m over the entire study area. In the first $50 \mathrm{~m}$, nitrate was inferior to the detection limit $(0.05 \mu \mathrm{M})$ at all sites and silicic acid ranged from $0.2 \mu \mathrm{M}$ in $\mathrm{A} 2$ to $0.5 \mu \mathrm{M}$ in $\mathrm{A} 1$.

[17] Integrated nutrient stocks (over $80 \mathrm{~m}$ ) were determined at all sites and compared for each cruise in order to assess the seasonal evolution of biological drawdown (Figure 3). During winter, the integrated silicic acid stock increased by $30 \%$ from south to north, with the highest stock in A1 $\left(200 \mathrm{mmol} \mathrm{Si} \mathrm{m}^{-2}\right)$. During spring, less than $15 \%$ of the winter silicic acid stock was depleted in the southern part of the study area (A2 and C4) while Si utilization increased up to $47 \%$ in the northern region (A1). In the late summer, Si stocks were low and homogeneous over the entire region $\left(40-57 \mathrm{mmol} \mathrm{m}^{-2}\right)$. Integrated nitrate stocks followed approximately the same distribution, with a south-north increasing gradient during winter and a stronger depletion in A1 than in C4 during spring. However, the rate of depletion was much higher between $\mathrm{P} 1$ and P2 than for silicic acid, with a $50 \%$ decrease of the nitrate stock at both $\mathrm{A} 2$ and A1, and a $30 \%$ decrease in $\mathrm{C} 4$. In the late summer, nitrate was depleted in the surface layer over the entire region and stocks ranged from $48 \mathrm{mmol} \mathrm{N} \mathrm{m}^{-2}$ in C4 to $96 \mathrm{mmol} \mathrm{N} \mathrm{m}^{-2}$ in A1.

\subsection{Integrated Particulate Matter Distribution and Primary Production}

[18] Total biogenic silica (BSi) profiles are presented for the three mesoscale structures which were revisited throughout the year (A1, C4 and A2) for the 0-100 m layer (Figure 4). The winter BSi concentrations were low and homogeneous over the $0-60 \mathrm{~m}$ layer $\left(0.04-0.14 \mu \mathrm{mol} \mathrm{L}^{-1}\right)$, but slightly higher than the late summer values $(0.01-$

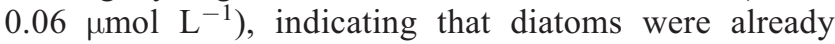
growing by the end of February. By April-May (P2), the diatom spring bloom was well developed, with a peak BSi concentrations of $0.61 \mu \mathrm{mol} \mathrm{L}{ }^{-1}$ at $10 \mathrm{~m}$ in $\mathrm{C} 4$ and a deeper maximum of $0.88 \mu \mathrm{mol} \mathrm{L}^{-1}$ between 30 and $60 \mathrm{~m}$ in $\mathrm{A} 1$. In A2 however, BSi concentrations remained much lower, reflecting the lower silicic acid stock utilization, and a low maximum value of $0.18 \mu \mathrm{mol} \mathrm{L}{ }^{-1}$ was observed at $40 \mathrm{~m}$. Size-fractionated integrated $B$ Si $(0.6-10 \mu \mathrm{m}$ and $>10 \mu \mathrm{m})$ was measured at each site during winter and spring, but were not carried out in the late summer due to the very low diatom abundance (Figure 4). In the winter, the contribution of small diatoms $(<10 \mu \mathrm{m})$ increased regularly from south to north, representing 34\% in A2, 48\% in C4 and 69\% in A1. During spring, large diatoms $>10 \mu \mathrm{m}$ were slightly dominant in both $\mathrm{A} 2$ and $\mathrm{C} 4$ (with an equal contribution of $58 \%$ ) and constituted up to $76 \%$ of the total $B$ Si stock in A1.

[19] Total integrated BSi, pigment stocks and primary production ( $\Sigma P P$ ) for the three revisited sites are presented in Figure 5. A strong seasonal pattern was observed for both BSi and fucoxanthin stocks, with a strong increase between $\mathrm{P} 1$ and P2. BSi stocks presented a weak spatial variability during winter, with fairly similar concentrations ranging from 4 to $8 \mathrm{mmol} \mathrm{Si} \mathrm{m}{ }^{-2}$. On the other hand, fucoxanthin stocks showed an increase from south to north already in the winter, as stocks more than tripled in A1 compared to A2. During spring, the intersite variability rose sharply and BSi stocks increased by a factor 2, 3, and 7 from south to north respectively. The overall highest stock during the POMME cruises was measured in A1 in May $\left(61 \mathrm{mmol} \mathrm{Si} \mathrm{m}^{-2}\right)$. This latitudinal gradient pattern was conserved during spring for fucoxanthin, but the increasing factor between winter and spring stocks was much less than for $B \mathrm{Si}$ and ranged from 2 to 3. Similarly to $B \mathrm{Si}$, the highest fucoxanthin stock was observed in $\mathrm{A} 1$ in the spring $\left(15 \mathrm{mg} \mathrm{m}^{-2}\right)$.

[20] The seasonal evolution of the integrated $\mathrm{Chl} a$ stocks were quite distinct from the diatom components $(B \mathrm{Si}$ and fucoxanthin) evolution, with already elevated stocks during winter period (38-64 $\mathrm{mg} \mathrm{m}^{-2}$ ), followed by a very slight increase during spring. The integrated $\mathrm{Chl} a$ stocks increased by only $3 \%$ in $\mathrm{A} 2$ and $21 \%$ in $\mathrm{C} 4$ between $\mathrm{P} 1$ and P2. Surprisingly, Chl $a$ stocks decreased by $24 \%$ in A1 during spring, contrary to the strong $\mathrm{BSi}$ and fucoxanthin increase at this site. In the late summer, the $B \mathrm{Si}$ and pigments stocks were lower than winter values at all sites, and were homogeneously distributed from north to south, with a slightly higher remaining fucoxanthin and Chl $a$ stocks in A1 than at the other sites.

[21] Integrated primary production ( $\Sigma \mathrm{PP}$ over $80 \mathrm{~m}$ ) distribution was closer to Chl $a$ than to the siliceous components distribution. The south-north increasing gradient was clear during winter, with a $35 \%$ increase of the $\Sigma$ $\mathrm{PP}$ between $\mathrm{A} 2$ and $\mathrm{A} 1$. In the spring however, the $\Sigma \mathrm{PP}$ distribution differed from that of other parameters. The strongest increase in $\Sigma$ PP was observed in A2 $(+32 \%)$ while the smallest increase was measured in A1 $(<2 \%)$, where the $\Sigma P P$ was already high during winter $(62.1 \mathrm{mmol} \mathrm{C}$ $\left.\mathrm{m}^{-2} \mathrm{~d}^{-1}\right)$. Furthermore, the $\Sigma \mathrm{PP}$ decreased in $\mathrm{C} 4$ from 
A2

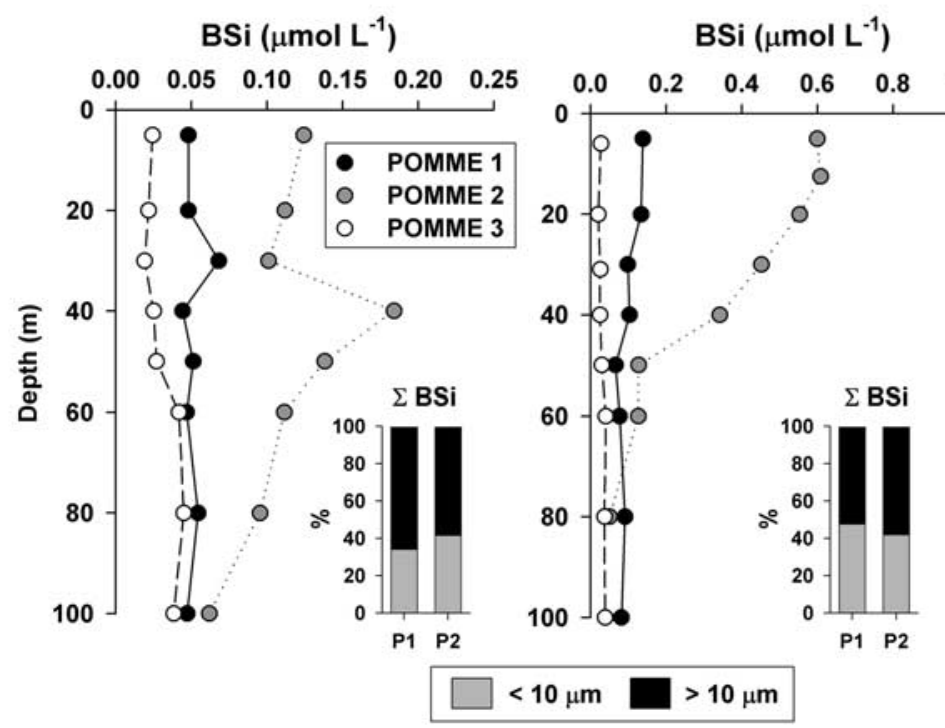

South
A1

BSi $\left(\mu \mathrm{mol} \mathrm{L}{ }^{-1}\right)$

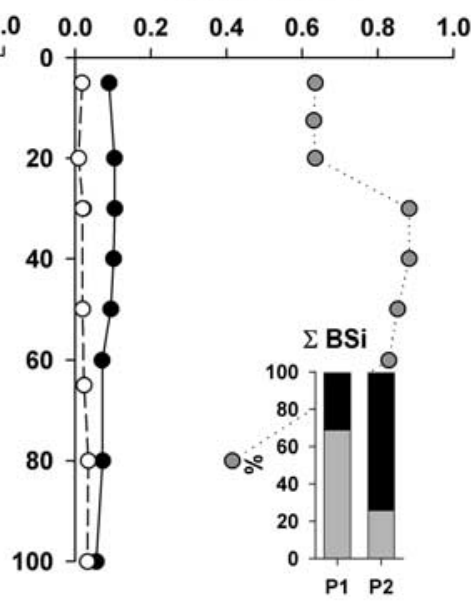

Figure 4. Biogenic silica $(B \mathrm{Si})$ profiles for the $0-100 \mathrm{~m}$ layer for the three cruises at the southern anticyclonic eddy $\mathrm{A} 2$, the cyclonic eddy $\mathrm{C} 4$, and the northern anticyclonic eddy A1. The histograms present the percentage of small and large diatoms $(<10$ and $>10 \mu \mathrm{m})$ to integrated $B \mathrm{Si}(\Sigma B \mathrm{Si})$ for POMME 1 (P1) and POMME 2 (P2).

$53.9 \mathrm{mmol} \mathrm{C} \mathrm{m}^{-2} \mathrm{~d}^{-1}$ in the winter to $38.9 \mathrm{mmol} \mathrm{C} \mathrm{m}^{-2} \mathrm{~d}^{-1}$ in the spring $(-28 \%)$. The lowest $\Sigma \mathrm{PP}$ values were measured in the late summer and ranged from 12.9 to $18.9 \mathrm{mmol} \mathrm{C} \mathrm{m}{ }^{-2} \mathrm{~d}^{-1}$ from south to north.

\subsection{Si Uptake Rates and Uptake Kinetics $\left(V_{\max }, K_{S}\right)$}

[22] The seasonal evolution of silicic acid uptake rates for A2, C4 and A1 is presented in Figure 6. In the winter, uptake rates were low in the first $50 \mathrm{~m}$ and reached a maximum of $0.04 \mu \mathrm{mol} \mathrm{Si} \mathrm{L}{ }^{-1} \mathrm{~d}^{-1}$ in A1 at $20 \mathrm{~m}$. In the spring, Si uptake rates increased significantly in the surface layer, but remained low at both $\mathrm{A} 2$ and $\mathrm{C} 4$ sites, contrary to $\mathrm{BSi}$ concentrations, which increased sharply in C4 (Figure 4). The increase in $\mathrm{Si}$ uptake rates followed a south-north gradient, and the highest values were measured in A1 at the surface $\left(0.33 \mu \mathrm{mol} \mathrm{Si} \mathrm{L}{ }^{-1} \mathrm{~d}^{-1}\right)$ while a secondary peak was observed at $30 \mathrm{~m}\left(0.25 \mu \mathrm{mol} \mathrm{Si} \mathrm{L} \mathrm{L}^{-1} \mathrm{~d}^{-1}\right)$. Si uptake rates were the lowest ever measured in any open ocean system during late summer cruise, with uptake rates below $0.001 \mu \mathrm{mol} \mathrm{Si} \mathrm{L}{ }^{-1} \mathrm{~d}^{-1}$ at all sites over the entire $0-100 \mathrm{~m}$ layer.

[23] Size-fractionated integrated Si uptake rates over the $0-80 \mathrm{~m}$ layer showed a strong northward increase (from 34 to $81 \%)$ of the contribution of small diatoms $(<10 \mu \mathrm{m})$ to the production fluxes during winter (Figure 6). In the spring, the contribution of small diatoms was higher in A2 and C4 than in the winter, while a strong shift toward the dominance of large diatoms was observed in the A1, where diatoms $>10 \mu \mathrm{m}$ contributed to $91 \%$ of the $\Sigma$ Si uptake flux.

[24] Si uptake kinetic experiments were also conducted at two depths at each study site during P1 and P2. Out of the 16 kinetic curves obtained, 12 could be fitted by a Michae-
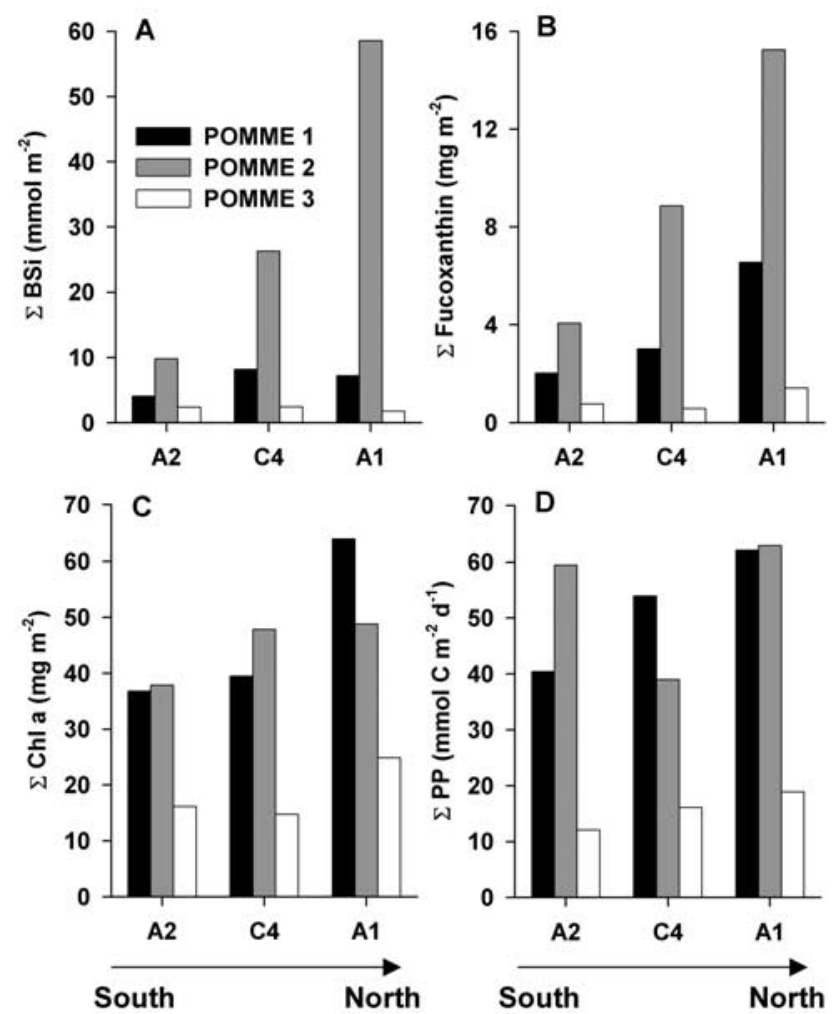

Figure 5. Integrated stocks (over $80 \mathrm{~m}$ ) of (a) $\mathrm{BSi}$ (mmol $\left.\mathrm{m}^{-2}\right)$, (b) fucoxanthin $\left(\mathrm{mg} \mathrm{m}^{-2}\right)$, (c) Chl $a\left(\mathrm{mg} \mathrm{m}^{-2}\right)$, and (d) integrated fluxes of primary production (PP) $(\mathrm{mmol} \mathrm{C}$ $\mathrm{m}^{-2} \mathrm{~d}^{-1}$ ) at the three revisited sites in the winter ( $\left.\mathrm{P} 1\right)$, spring (P2), and late summer (P3). 
A2

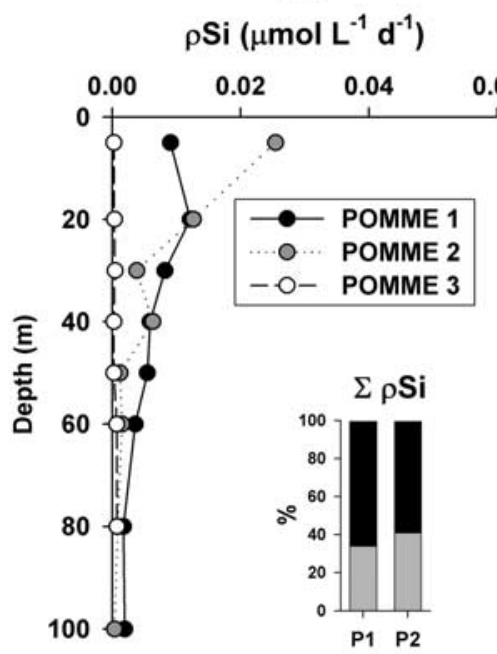

C4 $\rho \mathrm{Si}\left(\mu \mathrm{mol} \mathrm{L}{ }^{-1} \mathrm{~d}^{-1}\right)$
A1 $\rho$ Si $\left(\mu \mathrm{mol} \mathrm{L} \mathrm{L}^{-1} \mathrm{~d}^{-1}\right)$

$$
\begin{array}{|l|l|l}
\square<10 \mu \mathrm{m} & \square>10 \mu \mathrm{m}
\end{array}
$$

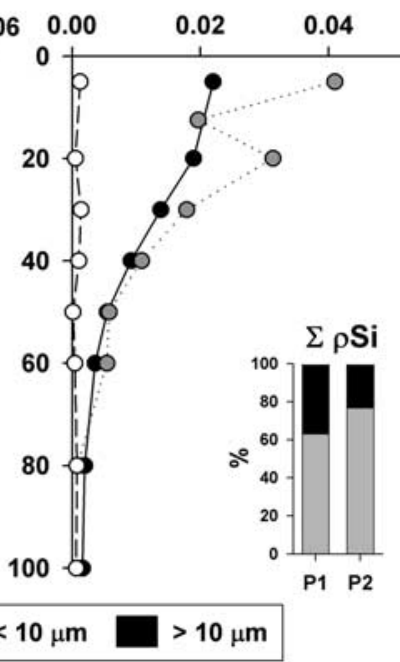

0.060.

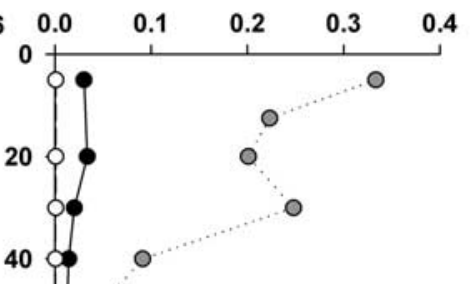

South

North

Figure 6. Si uptake rates profiles for the $0-100 \mathrm{~m}$ layer for the three cruises at the southern anticyclonic eddy $\mathrm{A} 2$, the cyclonic eddy $\mathrm{C} 4$, and the northern anticyclonic eddy $\mathrm{A} 1$. The histograms present the percentage contribution of small and large diatoms $(<10$ and $>10 \mu \mathrm{m})$ to integrated $\mathrm{Si}$ uptake rates $(\Sigma \rho \mathrm{Si}$ in mmol Si m ${ }^{-2} \mathrm{~d}^{-1}$ ) for P1 and P2.

lis-Menten curve (hyperbolic fit), 3 presented a linear response to increasing silicic acid concentrations, and 1 already reached plateau values for the minimal Si addition, thus not allowing to calculate $V_{\max }$ or $K_{S}$ parameters. Examples of the two main types of kinetic curves obtained (hyperbolic and linear) are presented in Figure 7. The calculated $V_{\max }$ and $K_{S}$ values are summarized in Table 2 and compared to measured in situ $V \mathrm{Si}$ and silicic acid concentrations. During P1, Si half-saturation constants were particularly high, ranging from 1.77 to $5.92 \mu \mathrm{M}$. The potential maximum specific $\mathrm{Si}$ uptake rates $\left(V_{\max }\right)$ ranged from 0.19 to $0.59 \mathrm{~d}^{-1}$, with an average value of $0.43 \mathrm{~d}^{-1}$ (Table 2). In this season, $K_{S} \mathrm{Si}$ were always superior to ambient silicic acid concentrations values while measured
$V \mathrm{Si}$ values represented between 22 and $65 \%$ of the calculated $V_{\max }$. During P2, $K_{S} \mathrm{Si}$ values decreased significantly $(P<0.0005, d f=7$, t-test $)$ at all sites and were composed between 0.72 and $1.26 \mu \mathrm{M}$, which was slightly inferior to ambient silicic acid concentrations. The average $V_{\max }$ value was $0.34 \mathrm{~d}^{-1}$, but the decrease between the winter and spring mean values was not significant $(P>0.05)$. The measured $V \mathrm{Si}$ values were again lower than the calculated maximal potential uptake rates and represented $11-46 \%$ of the $V_{\max }$ values. The $V_{\max } / K_{S}$ ratio, proportional to the initial slope of the curve, is often considered to be a better nutrient affinity indicator than either $V_{\max }$ or $K_{S}$ since both parameters can constrain the ability to take up nutrients at low concentrations [Healey, 1980; Franck et al., 2003]. The
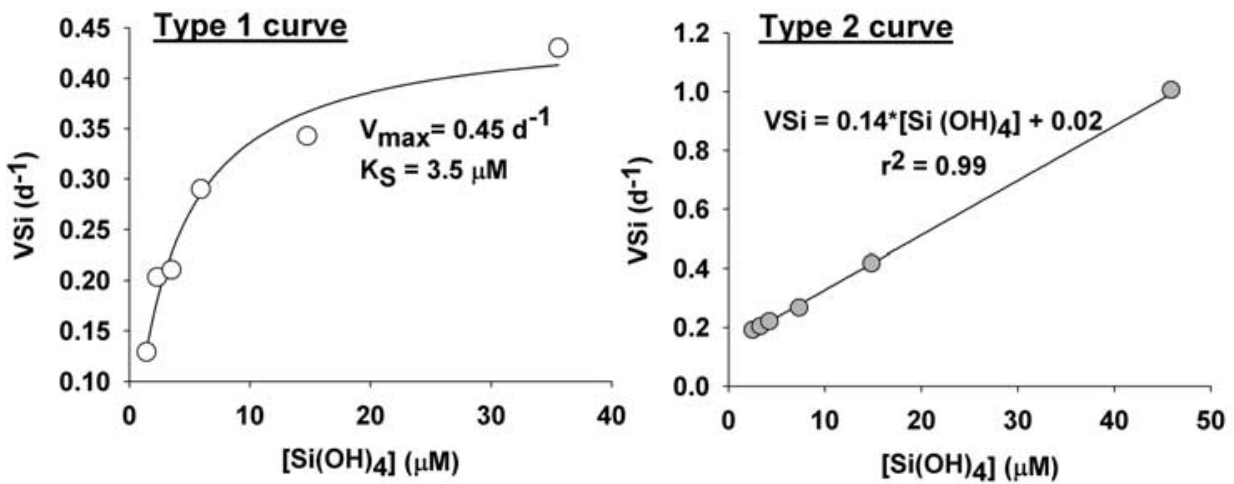

Figure 7. Examples of the two hyperbolic and linear types of kinetic Si uptake curves obtained during POMME 1 and 2. VSi, specific Si uptake rates $\left(\right.$ in $\left.^{-1}\right)$. 
Table 2. Si Uptake Kinetics During the Winter and Spring Season

\begin{tabular}{|c|c|c|c|c|c|c|c|c|c|c|c|c|}
\hline & \multicolumn{2}{|c|}{$K_{S} \mathrm{Si}^{\mathrm{a}}$} & \multicolumn{2}{|c|}{$\left[\mathrm{Si}(\mathrm{OH})_{4}\right]^{\mathrm{a}}$} & \multicolumn{2}{|c|}{$V_{\max }^{\mathrm{b}}$} & \multicolumn{2}{|c|}{$V \mathrm{Si}^{\mathrm{b}}$} & \multicolumn{2}{|c|}{$V \mathrm{Si} / V_{\max },{ }^{\mathrm{b}} \%$} & \multicolumn{2}{|c|}{$V_{\max } / K_{S}$} \\
\hline & $20 \mathrm{~m}$ & $40 \mathrm{~m}$ & $20 \mathrm{~m}$ & $40 \mathrm{~m}$ & $20 \mathrm{~m}$ & $40 \mathrm{~m}$ & $20 \mathrm{~m}$ & $40 \mathrm{~m}$ & $20 \mathrm{~m}$ & $40 \mathrm{~m}$ & $20 \mathrm{~m}$ & $40 \mathrm{~m}$ \\
\hline & & & & & & $P 1$ & & & & & & \\
\hline $\mathrm{A} 2$ & 3.50 & 1.77 & 1.58 & 1.72 & 0.45 & 0.21 & 0.25 & 0.13 & 55 & 65 & 0.13 & 0.12 \\
\hline $\mathrm{FZ}$ & 4.73 & 5.92 & 1.87 & 1.92 & 0.56 & 0.59 & 0.19 & 0.13 & 34 & 22 & 0.12 & 0.10 \\
\hline $\mathrm{C} 4$ & 4.10 & 4.50 & 2.37 & 2.12 & 0.41 & 0.19 & 0.14 & 0.09 & 34 & 47 & 0.10 & 0.04 \\
\hline A1 & 4.62 & $\operatorname{lin}$ & 2.40 & 2.50 & 0.61 & unsat & 0.32 & 0.14 & 52 & $\ldots$ & 0.13 & $\ldots$ \\
\hline & & & & & & $P 2$ & & & & & & \\
\hline $\mathrm{A} 2$ & lin & lin & 1.53 & 1.47 & unsat & unsat & 0.20 & 0.03 & $\ldots$ & $\ldots$ & $\ldots$ & $\ldots$ \\
\hline $\mathrm{C} 4$ & 0.94 & 0.84 & 1.53 & 2.47 & 0.54 & 0.14 & 0.06 & 0.03 & 11 & 21 & 0.57 & 0.17 \\
\hline SP & 1.26 & 0.85 & 1.36 & 1.32 & 0.55 & 0.24 & 0.23 & 0.11 & 42 & 46 & 0.44 & 0.28 \\
\hline $\mathrm{A} 1$ & nd & 0.72 & 1.29 & 1.03 & nd & 0.25 & 0.32 & 0.10 & $\ldots$ & 40 & $\ldots$ & 0.35 \\
\hline
\end{tabular}

${ }^{\mathrm{a}}$ Comparison of half-saturation constants for silicic acid $\left(K_{S} \mathrm{Si}\right.$ in $\left.\mu \mathrm{M}\right)$ with in situ silicic acid concentrations ([Si(OH)$\left.)_{4}\right]$ in $\left.\mu \mathrm{M}\right)$ for two depths at each study site during POMME 1 and 2 (P1 and P2): lin, linear uptake kinetics (type 2 curve in Figure 8); nd, not determined, no curve could be fitted to the data points.

${ }^{b}$ Comparison of maximum specific Si uptake rates $\left(V_{\max }\right.$ in $\left.\mathrm{d}^{-1}\right)$ with in situ specific Si uptake rates $\left(V \mathrm{Si}\right.$ in $\left.\mathrm{d}^{-1}\right)$ for two depths at each study site during POMME 1 and 2: unsat, linear response (type 2 curve in Figure 8), no plateau reached; nd, not determined.

$V_{\max } / K_{S}$ ratios appeared significantly increased in spring compared to winter values, with an increase on average by a factor $4-5$ at $20 \mathrm{~m}$ and by a factor 3 at $40 \mathrm{~m}$.

\subsection{Diatom Contribution to Primary Production}

[25] Diatom contribution to primary production was estimated using an average $\mathrm{Si} / \mathrm{C}$ ratio to convert integrated $\mathrm{Si}$ uptake rates into $\mathrm{C}$ equivalents. $\mathrm{A} \mathrm{Si} / \mathrm{C}$ ratio of 0.09 was used for the small diatom fraction $(<10 \mu \mathrm{m})$ and a $\mathrm{Si} / \mathrm{C}$ ratio of 0.13 was used for the large diatoms [Brzezinski, 1985]. The converted $\mathrm{C}$ uptake rates were compared to the actual in situ $\Sigma$ PP measurements and the contribution of diatoms to total phytoplankton $\Sigma$ PP was mapped for each cruise (Figure 8). As indicated by other siliceous biomass components (BSi, fucoxanthin, $\rho \mathrm{Si}$ ), the contribution of diatoms to $\Sigma$ PP increased from south to north at all seasons. This contribution increased from $12 \%$ in A2 to $25 \%$ in A1 during winter. In the spring, diatoms contribution to $\Sigma$ PP remained unchanged in the A2, but increased drastically northward and accounted for $100 \%$ of the $\Sigma P P$ in A1. During late summer, this contribution decreased sharply and was insignificant over the entire study area $(2-4 \%)$.

\subsection{Si Export Fluxes}

[26] BSi daily export fluxes were measured in drifting sediment traps at $200 \mathrm{~m}$ and $400 \mathrm{~m}$ at each study site (Figure 9). BSi fluxes were corrected for dissolution in the collecting cups. The percentage of $B \mathrm{Si}$ dissolution ranged between 0 and $50 \%$ throughout the study. The measured dissolution rates were moderate during winter (18\%), increased during spring (34\%) and were minimal during late summer $(9 \%)$. In terms of absolute quantity, the corrected $B$ Si fluxes were reevaluated on average by $22 \%$ compared to the uncorrected values.

[27] During both the winter and spring, BSi daily fluxes increased from south to north, following the pattern observed for biomass and production rates. In the winter, $B$ Si fluxes at $200 \mathrm{~m}$ increased from 0.2 to $29.0 \mu \mathrm{mol} \mathrm{Si}$
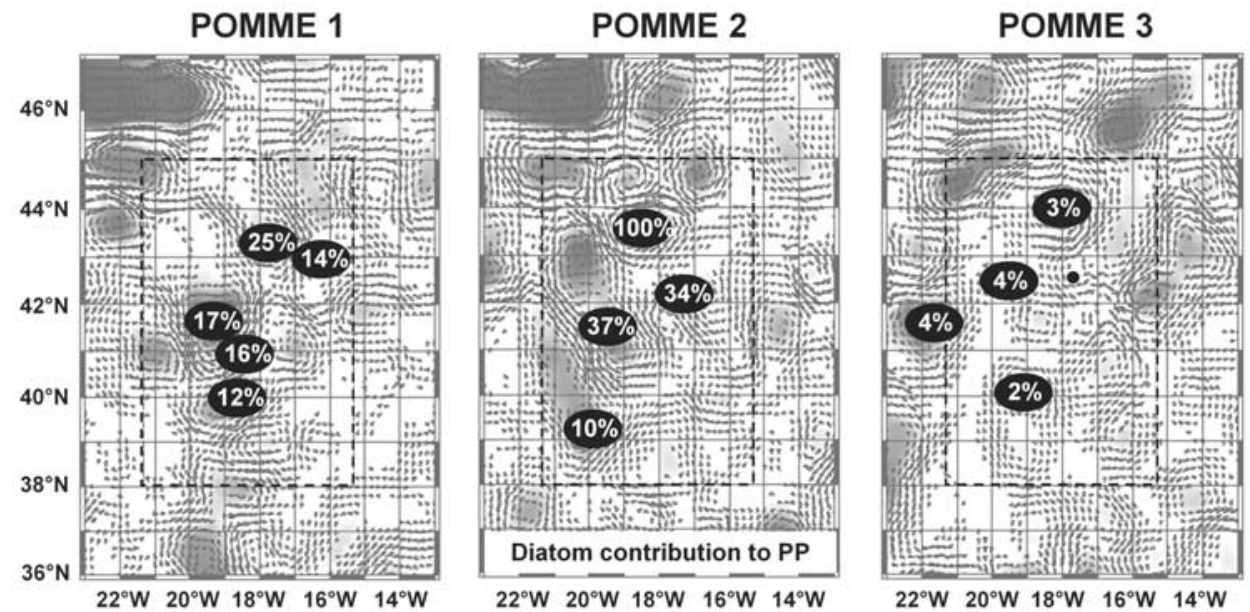

Figure 8. Diatoms contribution to integrated primary production $(0-100 \mathrm{~m})$ at the different study sites for each cruise. $\mathrm{Si} / \mathrm{C}$ ratios of $0.09-0.13$ were used to convert $\mathrm{Si}$ production into $\mathrm{C}$ equivalent. 

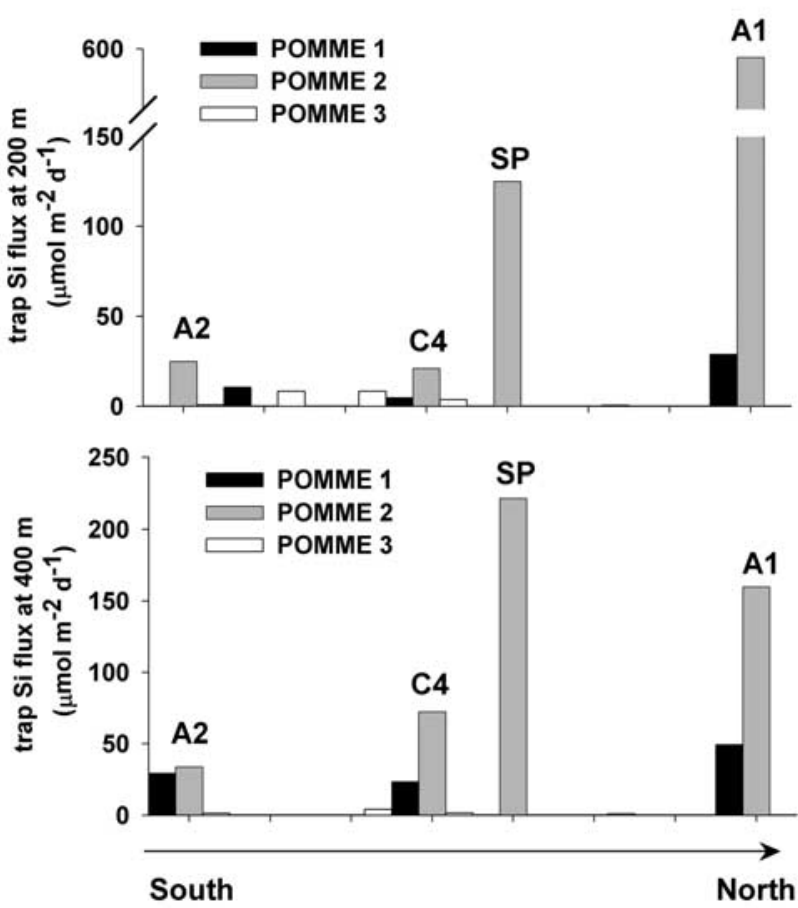

Figure 9. Biogenic silica fluxes $\left(\mathrm{mmol} \mathrm{m} \mathrm{m}^{-2} \mathrm{~d}^{-1}\right)$ in sediment traps at 200 and $400 \mathrm{~m}$ along a south-north gradient for all three seasons.

$\mathrm{m}^{-2} \mathrm{~d}^{-1}$ from $\mathrm{A} 2$ to A1. BSi fluxes increased significantly during spring, and ranged from 24.8 to $586.0 \mu \mathrm{mol} \mathrm{Si}$ $\mathrm{m}^{-2} \mathrm{~d}^{-1}$ from south to north. During P1 and P2, fluxes at $400 \mathrm{~m}$ were always superior to the fluxes measured at $200 \mathrm{~m}$, except in A1, where the flux decreased by a factor 3.6. During spring, the maximum $\mathrm{Si}$ flux at $400 \mathrm{~m}$ was recorded at $42^{\circ} \mathrm{N}\left(221.8 \mu \mathrm{mol} \mathrm{Si} \mathrm{m} \mathrm{d}^{-1}\right)$ and not in $\mathrm{A} 1$, where the upper trap collected the highest flux. In the late summer, fluxes were negligible at both depths (mean $\mathrm{Si}$ flux: $2.7 \mu \mathrm{mol} \mathrm{Si} \mathrm{m} \mathrm{m}^{-2} \mathrm{~d}^{-1}$.

\section{Discussion}

\subsection{Onset of the Bloom: The South-North Gradient Compared to Mesoscale Features}

[28] The first phase of the bloom occurs after the alleviation of light limitation in the North Atlantic, following the spring stratification of the surface layer [Sverdrup, 1953]. Heat fluxes toward the ocean became positive at the end of February [Caniaux et al., 2005a, 2005b]. The CARIOCA buoys dispatched throughout the study area indicated the start of a biological uptake of $\mathrm{CO}_{2}$ by 1 April, in parallel with an increase in fluorescence [Mémery et al., 2005]. This discrepancy may be explained by the frequency and intensity of wind stress in this region, likely to delay the onset of stratification in the surface layer [Stramska et al., 1995]. Satellite derived zonal integrations of $\mathrm{Chl} a$ concentrations indicated a northward progression of the spring bloom between April and May, when the peak Chl a level progressed from $40^{\circ}-41^{\circ} \mathrm{N}$ to $45^{\circ} \mathrm{N}$ [Lévy et al., 2005]. Each leg of the POMME cruises were carried out over 25 days and $4^{\circ}$ of latitude, meaning that the synopticity of these results is not likely. Thus the south-north gradient observed for most of our data results partly from (1) a spatial variability, induced by the differences in available nutrient stocks created by the northward increase of the winter mixed layer depth (MLD) and (2) a temporal variability, as the bloom progresses northward following increased heat fluxes and the propagation of the thermal stratification. The interpretation of the data from the second legs is thus relatively complex, but the diatoms distribution appeared more influenced by the latitudinal progression of the bloom rather than by the influence of the different mesoscale features (anticyclonic and cyclonic eddies). Indeed, the siliceous biomass, $\mathrm{Si}$ uptake rates and diatoms contribution to primary production increased regularly from south to north (Figures 4, 5, 6, and 8).

\subsection{Diatom Seasonal Dynamics in the Eastern North Atlantic}

\subsubsection{Diatom Distribution}

[29] Diatom biomass indicators as well as $\mathrm{Si}$ production fluxes were poorly correlated to any other parameter such as nutrient stocks and primary production. In an attempt to reconstruct a temporal evolution of the diatom bloom, integrated $B \mathrm{Si}$, fucoxanthin and $\rho \mathrm{Si}(0-80 \mathrm{~m})$ were represented following a decreasing integrated $(0-80 \mathrm{~m})$ silicic acid gradient by combining data for all sites and all seasons (Figure 10). According to Brown et al. [2003], Si acid uptake rates could be predicted from the average photic silicic acid concentrations in the North Atlantic. This relationship was not evident in our study, whether we considered the mean photic zone average concentrations (data not shown) or the $0-80 \mathrm{~m}$ integrated stocks of silicic acid (Figure 10). Integrated $B S i$, fucoxanthin and Si uptake fluxes were highly correlated throughout the survey, but did not show any correlation with integrated silicic acid, nitrate or Chl $a$. However, both nitrate and silicic acid integrated stocks showed a good correlation with integrated Chl $a$. Thus a more detailed study of nutrient distribution pattern was necessary to investigate the main factor controlling the evolution of the diatom bloom.

\subsubsection{Limiting Factors: Evidence for Si Limitation}

[30] In the spring, the North Atlantic production regime is mainly controlled by the availability of nutrients once the surface layer stratification has occurred [Longhurst et al., 1995]. In the North Atlantic, the potential limiting role of silicic acid of the diatom spring bloom has been pointed out through field studies and modeling work [Lochte et al., 1993; Sieracki et al., 1993; Passow and Peinert, 1993; Taylor et al., 1993; Savidge et al., 1995; Bury et al., 2001].

[31] During winter, silicic acid availability was already $2-3 \mu \mathrm{M}$ lower than nitrate and integrated stocks were on average twice as low $\left(135-200 \mathrm{mmol} \mathrm{Si} \mathrm{m}^{-2}\right.$ compared to 280-415 mmol $\mathrm{N} \mathrm{m}^{-2}$ ). This deficit in $\mathrm{Si}$ was already observed at $1000 \mathrm{~m}$ in deep waters, where nitrate concentrations were 5-7 $\mu \mathrm{M}$ higher than silicic acid values (deep profiles not shown), implying a smaller initial input of Si compared to $\mathrm{N}$ to the surface layer through winter vertical mixing. The low $\mathrm{Si}: \mathrm{N}$ ratios in intermediate waters are explained by a slower dissolution rate of $B \mathrm{Si}$ during particulate matter sinking compared to $\mathrm{N}$ regeneration. Along the conveyor belt circulation through the world oceans, waters below the euphotic zone tend to accumulate $\mathrm{Si}$ which is less readily recycled in the water column than N. 

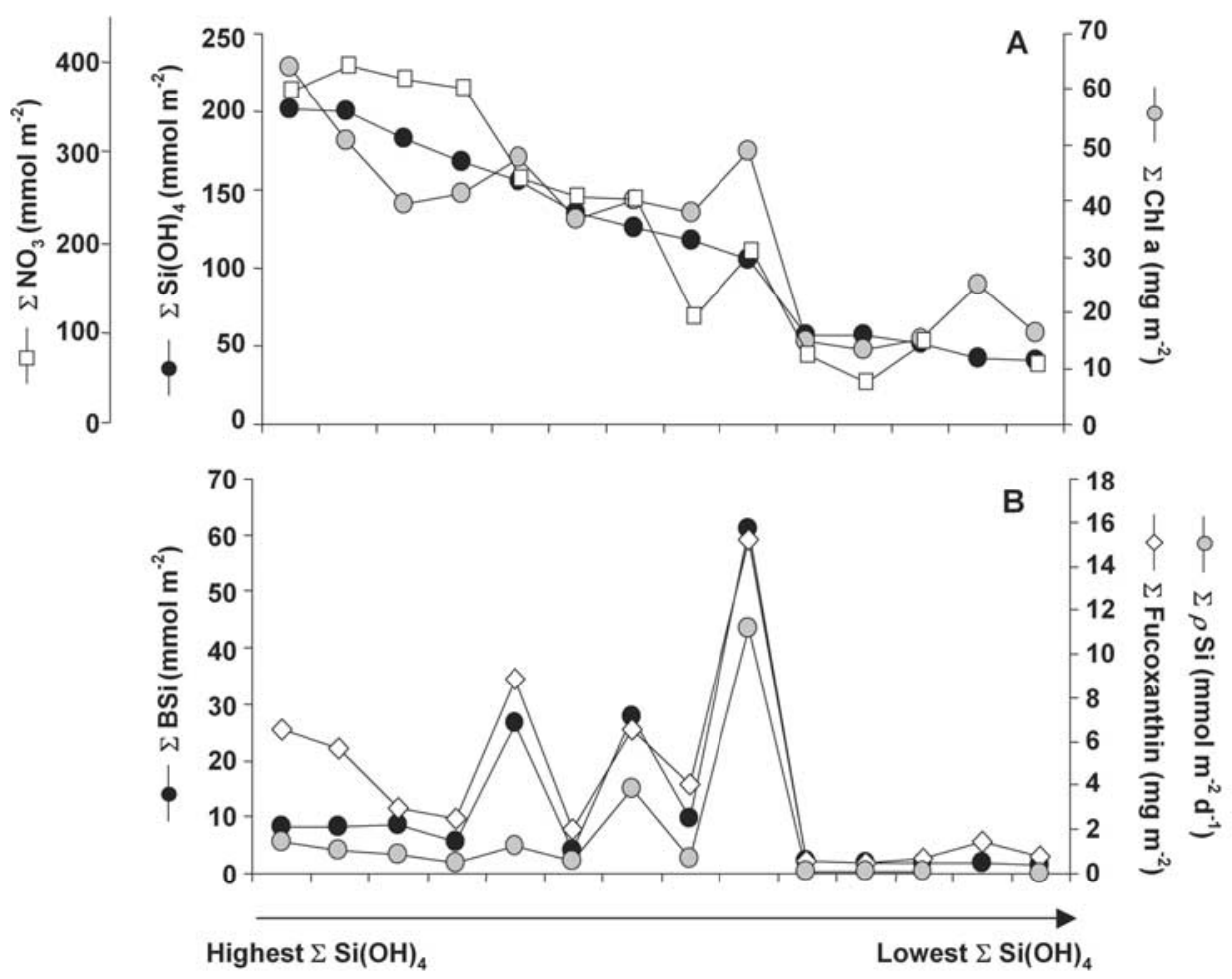

Figure 10. Combining the results from all three seasons, the data for each site presented in order of decreasing integrated $(0-80 \mathrm{~m})$ silicic acid gradient $\left(\mathrm{mmol} \mathrm{m}^{-2}\right)$ following the $x$ axis. (a) Corresponding integrated nitrate $\left(\mathrm{mmol} \mathrm{m}^{-2}\right)$ and $\mathrm{Chl} a\left(\mathrm{mg} \mathrm{m}^{-2}\right)$ and (b) $B \mathrm{Si}\left(\mathrm{mmol} \mathrm{m}^{-2}\right)$, fucoxanthin $\left(\mathrm{mg} \mathrm{m}^{-2}\right)$, and Si uptake rates $\left(\mathrm{mmol} \mathrm{Si} \mathrm{m}{ }^{-2} \mathrm{~d}^{-1}\right)$ values $(0-80 \mathrm{~m})$ for each site plotted according to the same decreasing silicic acid gradient.

A steady increase of the Si:N nutrient ratio at $250 \mathrm{~m}$ has thus been observed between the starting point of the conveyor belt in the Atlantic Ocean with Si:N ratios close to 0.5 and the North Pacific Ocean which receives older deep waters with $\mathrm{Si}: \mathrm{N}$ ratios $>1.5$ [Ragueneau et al., 2000]. The deficit in $\mathrm{Si}$ in the North Atlantic seems to be a recurrent feature and was also observed in the western basin in the Sargasso Sea by Brzezinski and Nelson [1996] who reported a mean $\mathrm{Si}: \mathrm{N}$ ratio at the basis of the euphotic layer as low as 0.25. During the North Atlantic Bloom Experiment (NABE) program, Sieracki et al. [1993] indicated a faster depletion of silicic acid relative to nitrate following the onset of the spring bloom at $46^{\circ} \mathrm{N}$ and $18^{\circ} \mathrm{W}$, just north of the POMME study area. These authors measured silicic acid concentrations as low as $0.2 \mu \mathrm{M}$ in May, which is extremely low for an open ocean regime. Comparable values were also recorded in the subtropical region of the North Atlantic $\left(33^{\circ} \mathrm{N}-21^{\circ} \mathrm{W}\right)$ by Passow and Peinert [1993], who documented concentrations $<0.2 \mu \mathrm{M}$ over the entire $0-200 \mathrm{~m}$ layer, while the depth of the nitracline oscillated between 60 and $80 \mathrm{~m}$. During the POMME cruises, such low silicic acid concentrations were only observed during late summer survey, when dissolved Si varied between 0.2 and $0.6 \mu \mathrm{M}$ in the $0-50 \mathrm{~m}$ layer. However, it is likely that $\mathrm{Si}$ was already depleted in the late spring, as both the CARIOCA buoys deployed in the study area and the Sea-viewing Wide Field-of-view Sensor (SeaWiFS) images indicated that the peak of the spring bloom occurred in April in the south and in May in the north of the POMME area, the latter being only partially sampled by the end of the second leg of P2.

[32] In order to determine the potential limiting factor of the diatoms spring bloom, in the sense of Liebig's law of minimum, we examined the integrated nutrient ratios in the surface layer compared to the empirical ratio $\mathrm{Si}: \mathrm{N}: \mathrm{P}=$ 16:16:1 [Brzezinski, 1985; Redfield et al., 1963], which gives an estimate of their nutrient requirement. Integrated Si:N and N:P ratios were calculated over the $0-80 \mathrm{~m}$ layer for all sites. In the winter, the $\Sigma \mathrm{Si}: \mathrm{N}$ ratios were systematically $<0.5$ and increased slightly during spring (Figure 11a). The highest value was observed in A2 (0.74) where nitrate was depleted more rapidly. In the late summer, silicic acid availability compared to nitrate increased in $\mathrm{C} 4(\Sigma \mathrm{Si}: \mathrm{N}=1.12)$ and particularly in $\mathrm{A} 1(\Sigma \mathrm{Si}: \mathrm{N}=5.30)$. At the other sites, the ratio remains $<1$, indicating a concomittant depletion of silicic acid and nitrate. The $\Sigma \mathrm{N}: \mathrm{P}$ ratios indicated a slight $\mathrm{P}$ deficit in the winter period (Figure 11b), with ratios $>16$ in A2, C4 and A1 eddies (17.3-21.1). In the spring and late summer, the $\Sigma \mathrm{N}: \mathrm{P}$ ratio indicated a constant deficit of $\mathrm{N}$ compared to $\mathrm{P}$ with much lower values $(7.5-12.8)$.

[33] All data points collected during the POMME cruises for which nitrate, silicic acid and phosphate concentrations were measured concurrently between 0 and $80 \mathrm{~m}$ were summarized in Figure 12, where the $\mathrm{Si}: \mathrm{N}=1, \mathrm{Si}: \mathrm{P}=16$ and $\mathrm{N}: \mathrm{P}=16$ lines delimit six areas, each characterizing a different hierarchy for the potential limiting factors. A seasonal shift of the potential limiting nutrient is clear: in 

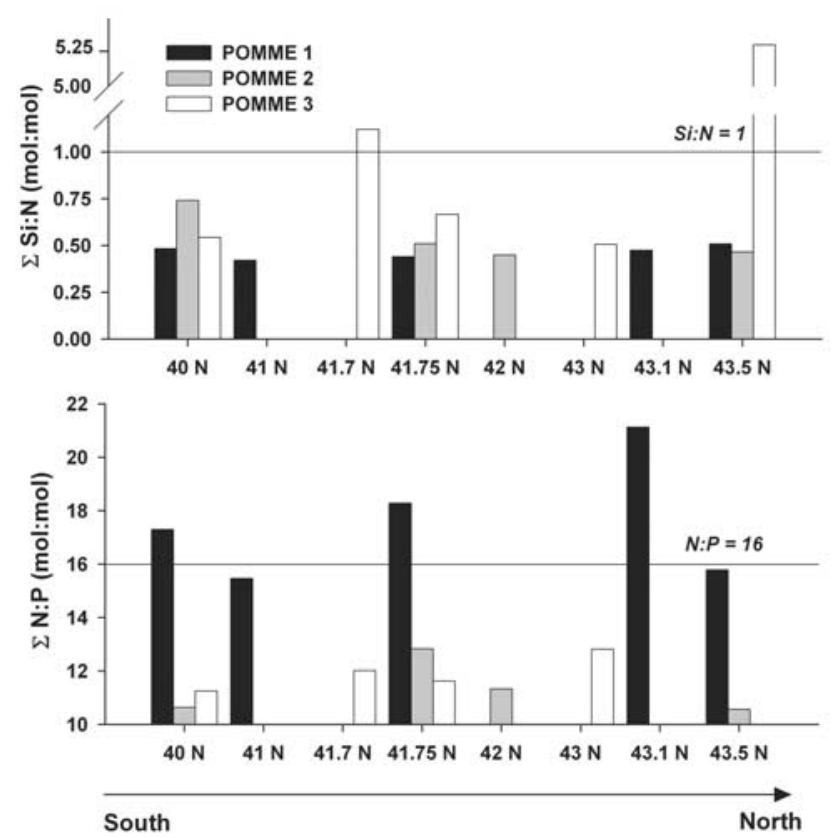

Figure 11. Integrated silic acid:nitrate ratios (mol:mol) and nitrate:phosphate ratios (mol:mol) along a south-north gradient for the three seasons. the winter, $\mathrm{Si}$ appears to be the first potential limiting nutrient, then followed by $\mathrm{P}$ and $\mathrm{N}$ in decreasing importance. In the spring, Si remained the first potential limiting nutrient while $\mathrm{N}$ was the secondary limiting nutrient followed by P. In the late summer, the nutrient status changed drastically toward a strong primary limitation by $\mathrm{N}$.

[34] While the comparison of ambient nutrients with the empirical Si:N:P ratio gives an indication on the hierarchy of the potential limiting nutrients, this approach is not sufficient in itself to determine the degree of limitation by one element. Nutritional limitation depends on an equilibrated supply of Si:N:P but also on the physiological status of phytoplankton, which can present various degrees of adaptation to low nutrient levels, on the specific community structure as well as on regeneration rates [Del Amo et al., 1997].

[35] Another way to assess the degree of limitation is to characterize the uptake kinetics of the considered element and to compare half-saturation constants $\left(K_{S}\right)$ with in situ concentrations. The Si uptake kinetic experiments conducted during winter and spring allowed us to give the first estimates for $K_{S} \mathrm{Si}$ values in the northeast Atlantic (Table 2). These results indicated relatively high values of $K_{S} \mathrm{Si}$ in the winter, with a mean $K_{S}=4.16 \mu \mathrm{M}$, in the high range of the values given in the literature $(0.4-5.0 \mu \mathrm{M})$ by Nelson and Tréguer [1992].

[36] The poor kinetic efficiency of diatoms may have been explained by light limitation at this season, but the thermal stratification already allowed a nonsiliceous phytoplankton to develop, as evidenced by the elevated $\Sigma$ Chl $a$

POMME 1

POMME 2

POMME 3
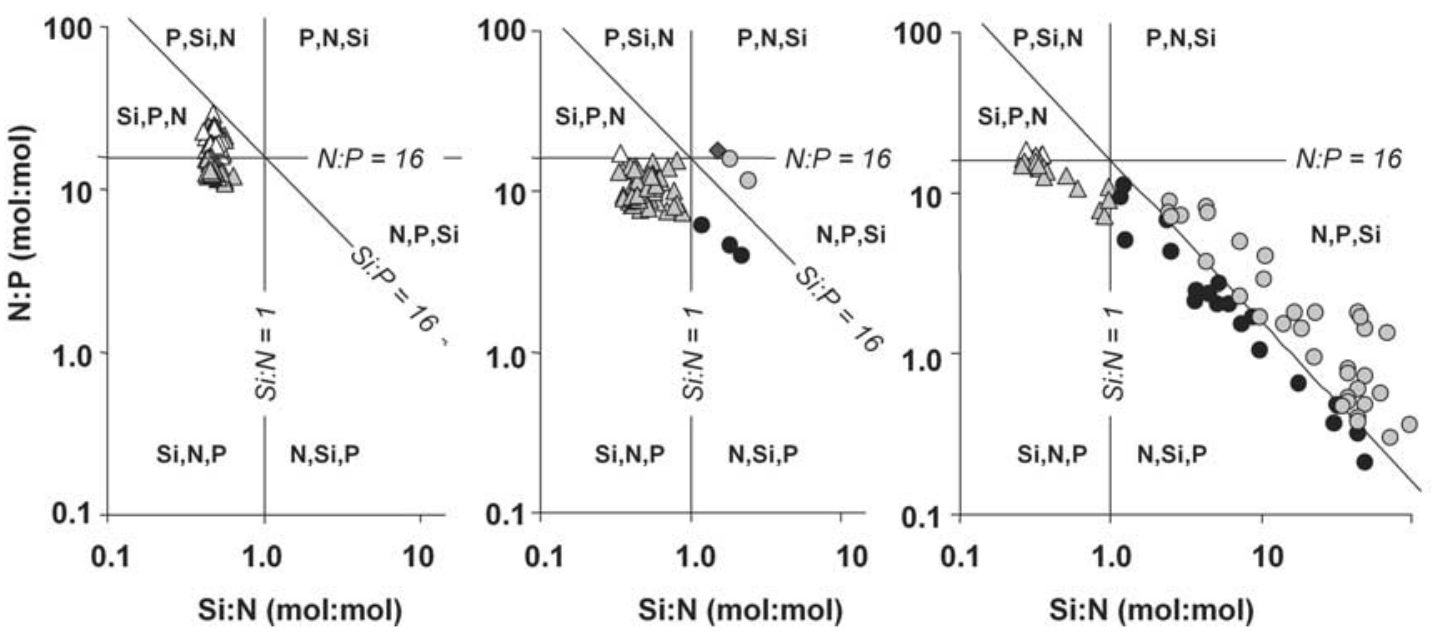

Figure 12. Si:N:P molar ratios of all nutrient data collected during each POMME cruise for the 0-80 m layer. Each area of the graph is delimited by straight lines representing the empirical Si:N:P $=16: 16: 1$ ratios [Brzezinski, 1985; Redfield et al., 1963]. Data with $\mathrm{Si}: \mathrm{N}$ values $<1$ show potential Si limitation, data with $\mathrm{N}: \mathrm{P}$ values $<16$ show potential $\mathrm{N}$ limitation, etc. A subsequent hierarchy of the order of importance of the potential limiting nutrient (PLN) can thus be attributed to each of the six areas delimited by the Si:N:P ratios. Different symbols were used for each area: open triangles, Si first potential limiting nutrient, followed by $\mathrm{P}$ and $\mathrm{N}$ in decreasing order of importance; shaded triangles, Si first potential limiting nutrient, followed by $\mathrm{N}$ and $\mathrm{P}$ in decreasing order of importance; solid circles, $\mathrm{N}$ first potential limiting nutrient, followed by $\mathrm{Si}$ and $\mathrm{P}$; shaded circles, $\mathrm{N}$ first potential limiting nutrient, followed by $\mathrm{P}$ and $\mathrm{Si}$; solid diamonds, $\mathrm{P}$ first potential limiting nutrient, followed by $\mathrm{N}$ and $\mathrm{Si}$. 


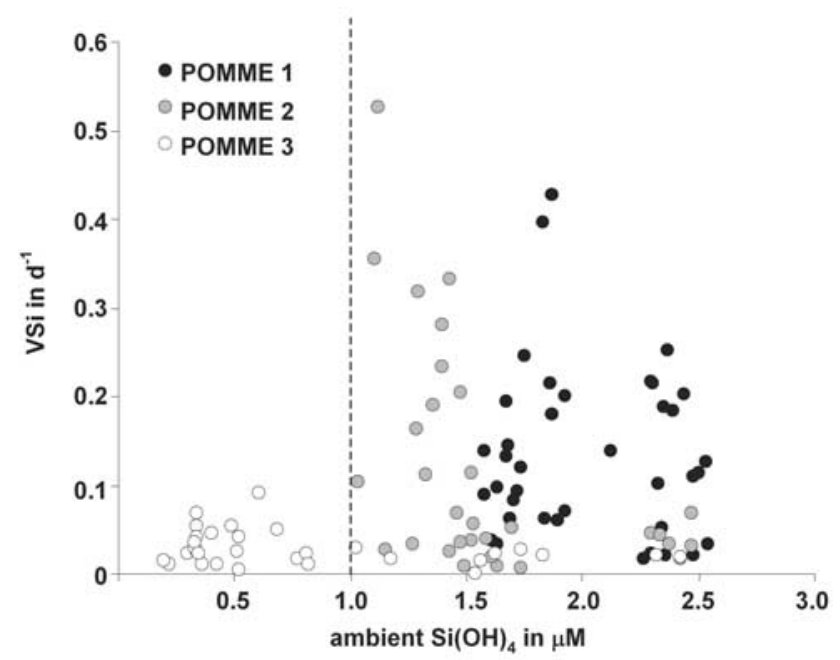

Figure 13. Specific Si uptake rates $\left(\mathrm{d}^{-1}\right)$ between 0 and $80 \mathrm{~m}$ as a function of in situ silicic acid concentrations (in $\mu \mathrm{M})$. The straight line delimits conditions for which silicic acid is $<1 \mu \mathrm{M}$.

and $\Sigma$ PP in the winter, while $\Sigma \mathrm{BSi}, \Sigma$ fucoxanthin and $\mathrm{Si}$ uptake rates were still very low (Figures 5 and 6). These results suggest that the alleviation of light limitation was already occurring in the winter, allowing the early onset of the annual phytoplankton bloom, but that diatoms growth was subject to strong Si limitation, as indicated by the $K_{S}$, $V_{\max }$ and $V_{\max } / K_{S}$ values as well as by the deficit in $\mathrm{Si}$ in the surface layer compared to other nutrients.

[37] In the spring, the lower mean $K_{S}$ value $(0.92 \mu \mathrm{M})$ and the increase in the affinity ratio $\left(V_{\max } / K_{S}\right)$ compared to the winter values suggest a better adaptation of diatoms to the low ambient Si concentrations. Nonetheless, the increase of Si uptake rates remained heterogeneous over the study area, with very low $\rho \mathrm{Si}$ in the southern/central region (A2 and $\mathrm{C} 4)$ and a large increase reflecting a bloom situation in the north (A1). While VSi still appeared strongly limited in that season, the increase of the $V \mathrm{Si} / V_{\max }$ ratio was higher in $\mathrm{A} 1$ $(40 \%)$ than in C4 $(11-21 \%)$, confirming diatoms increased growth rate and Si uptake efficiency at the northern site. It is likely that diatoms also encounter $\mathrm{N}$ limitation in the southern region, where nitrate decreased sharply between the winter and spring and where the $\Sigma \mathrm{Si}: \mathrm{N}$ ratios are highest (Figure 11). Nitrate concentrations were $<0.5 \mu \mathrm{M}$ in the surface layer, which is potentially limiting if one considers the average $K_{S} \mathrm{NO}_{3}$ given in the literature of $2 \mu \mathrm{M}$ [Del Amo et al., 1997]. In the North Atlantic, Savidge et al. [1995] attributed the decrease of diatoms growth rates to the diminution of silicic acid concentrations to values $<1 \mu \mathrm{M}$ and suggested simultaneous limitation of diatoms by both Si $(<0.8 \mu \mathrm{M})$ and $\mathrm{N}(<0.5 \mu \mathrm{M})$. During NABE, Sieracki et al. [1993] also attributed the decline of a spring Pseudo-Nitzschia bloom to the low availability of silicic acid.

[38] According to Nelson and Dortch [1996], the conditions least favorable to a diatom bloom are reached whenever silicic acid concentrations fall below $1.5 \mu \mathrm{M}$ in parallel to $\mathrm{Si}: \mathrm{N}$ ratios $<1$. Despite these nonfavorable conditions in the northern region $\left(\mathrm{Si}(\mathrm{OH})_{4}<1.3 \mu \mathrm{M}\right.$;
Si:N < 0.5), a Pseudo-Nitzschia bloom was observed in the A1 eddy during spring. This atypical bloom may result from a higher hivernal silicic acid stock in the surface layer compared to the other sites, as well as from a better adaptation of diatoms to the ambient silicic acid availability, as evidenced by the lowest $K_{S}$ value measured during spring $(0.72 \mu \mathrm{M})$. Furthermore, diatoms may adapt to low $\mathrm{Si}$ conditions by reducing the thickness of their frustules, since Si half-saturation constants for growth $(K \mu)$ are often much lower than half-saturation constants for uptake rates $\left(K_{S}\right)$ [Paasche, 1973; Nelson et al., 1976].

[39] The uptake of Si by diatoms has been demonstrated to follow a Michaelis-Menten curve with increasing substrate concentrations (type I curve (Figure 7)) [Paasche, 1980]. However, several studies have documented linear responses of uptake rates with increasing silicic acid concentrations comparable to the type II curve also observed in our study (Figure 7). Similar uptake kinetics were documented in the tropical Atlantic waters [Brzezinski and Nelson, 1996], in the central North Pacific [Brzezinski et al., 1998] and in the northeast Atlantic [Brown et al., 2003]. In this last study, the authors discuss the possibility that the linear fit represents the lower section of the hyperbolic curve. This is very unlikely in our study, since $\mathrm{Si}(\mathrm{OH})_{4}$ additions ranged from 0.5 to $50 \mu \mathrm{M}$, while $K_{S}$ values for oceanic systems (except in the Southern Ocean) are usually constrained between 0.4 and $5 \mu \mathrm{M}$ [Nelson and Tréguer, 1992]. In A1 during spring, the surface diatom community furthermore exhibited saturated uptake rates already at low silicic acid concentrations and $K_{S}$ and $V_{\max }$ could not be determined. These different types of responses may reflect distinct Si uptake models such as surge uptake, externally or internally controlled uptake [Martin-Jézéquel et al., 2000], which we hypothesize could depend on the relative external and internal Si pool as well as on the physiological state of the cells, and to some degree on a specific genetic variability. Clearly further studies aiming at identifying and characterizing the chain of enzymes and transporters involved in Si uptake are needed to understand the linear responses of $\mathrm{Si}$ uptake kinetics now documented for several oceanic systems.

[40] In situ measured VSi values did not show any linear relationship with ambient silicic acid concentrations (Figure 13) contrary to what was evidenced by Brzezinski et al. [1998] in the North Pacific. In this study, authors found that specific uptake rates were close to zero whenever silicic acid concentrations were $<1 \mu \mathrm{M}$. Despite the lack of clear relationship between VSi and silic acid during the POMME experiment, we still observed that $V \mathrm{Si}$ were always very low $\left(0.1 \mathrm{~d}^{-1}\right)$ below $1 \mu \mathrm{M}$ of $\mathrm{Si}$, indicating a strong limitation of uptake rates below this threshold. However, the sharp diminution of $V \mathrm{Si}$ values was observed during late summer and may also be the consequence of the extreme oligotrophic conditions observed, where nitrate and phosphate levels were low enough to initiate the decline of the microphytoplankton population. In the late summer, the increase of silicic acid concentration up to $2.5 \mu \mathrm{M}$ did not result in any further increase of $V \mathrm{Si}$ values (Figure 13), confirming the primary limiting role of nitrate and phosphate at this season. Similarly, the absence of linear relationship between $V \mathrm{Si}$ and dissolved $\mathrm{Si}$ in the winter and spring suggest the occurrence of simultaneous limitation by more 
Table 3. Comparative Table of Integrated Si Uptake Fluxes for the Entire POMME Area and Other Systems of the North Atlantic

\begin{tabular}{|c|c|c|c|c|c|}
\hline \multirow[b]{2}{*}{ Study Site } & \multirow[b]{2}{*}{ Latitude, ${ }^{\circ} \mathrm{N}$} & \multirow[b]{2}{*}{ Month } & \multicolumn{2}{|c|}{$\begin{array}{c}\sum \rho \mathrm{Si}, \\
\mathrm{mmol} \mathrm{\textrm {m } ^ { - 2 }} \mathrm{d}^{-1}\end{array}$} & \multirow[b]{2}{*}{ References } \\
\hline & & & Range & Mean & \\
\hline \multicolumn{6}{|l|}{ North Atlantic } \\
\hline POMME 1 & $40-43.5$ & March & $0.55-1.45$ & 0.90 & \multirow{3}{*}{ this study } \\
\hline POMME 2 & $40-43.5$ & April & $0.67-11.20$ & 4.25 & \\
\hline POMME 3 & $40-43.5$ & Sept.-Oct. & $0.04-0.08$ & 0.07 & \\
\hline Faeroes-Iceland-Scotland (FISHES) & $56-64$ & May & $6-167$ & 35.5 & Brown et al. [2003] \\
\hline North Atlantic (PAP site) & 48.8 & & $0.5-1.3$ & 0.9 & Ragueneau et al. [1997] \\
\hline \multirow[t]{2}{*}{ Sargasso Sea } & \multirow[t]{2}{*}{31.5} & yearly & $0.2-1.6$ & 0.5 & \multirow[t]{2}{*}{ Brzezinski and Nelson [1995]; Brzezinski and Kosman [1997] } \\
\hline & & April & $4.4-9.8$ & 7.1 & \\
\hline \multirow[t]{2}{*}{ Gulf Stream } & & June & $5.3-11.7$ & 7.3 & \multirow[t]{2}{*}{ Brzezinski and Nelson [1989] } \\
\hline & & Sept. -Oct. & $2.0-5.0$ & 3.4 & \\
\hline
\end{tabular}

than one element. Shipboard enrichment experiments conducted during the POMME experiment suggested that Si-Fe colimitation processes were also likely to limit diatom growth in this area [Blain et al., 2005], which is not usually considered to be an Fe-limited region due to the proximity of the continental shelf. However, low in situ Fe concentrations measured in the study area and a strong response to additions of both Fe and Saharan dusts on diatoms growth [Blain et al., 2005] contradicts the precedent assumption that the North Atlantic does not encounter Fe limitation.

\subsubsection{Seasonal Si Production and Export Budgets}

[41] Mean integrated Si production fluxes were calculated for each season in the POMME study area and compared to other production values measured in the North Atlantic (Table 3). There exists only a few studies documenting $\mathrm{Si}$ uptake rates in the North Atlantic and only two were carried out in the northeastern Atlantic. Integrated $\mathrm{Si}$ uptake rates measured north of our study area at the PAP site $\left(48.8^{\circ} \mathrm{N}\right)$ were very similar to our Si production budget calculated for the winter period with the same $\Sigma \rho \mathrm{Si}$ average of $0.9 \mathrm{mmol}$ $\mathrm{Si} \mathrm{m}{ }^{-2} \mathrm{~d}^{-1}$ [Ragueneau et al., 1997]. The range values of winter Si production fluxes was also very close to that found in the Sargasso Sea [Brzezinski and Nelson, 1995; Brzezinski and Kosman, 1997]. On the other hand, a study conducted between Iceland and Scotland between 56 and $64^{\circ} \mathrm{N}$ documented the highest production rates measured in the North Atlantic Ocean (maximum of $167 \mathrm{mmol} \mathrm{Si} \mathrm{m}^{-2}$ $\mathrm{d}^{-1}$ ) [Brown et al., 2003], one to two orders of magnitude higher than the rates measured in the present study. During the productive period, the range of $\Sigma \rho \mathrm{Si}$ values during POMME was in the same order of magnitude than those found in warm eddies of the Gulf Stream [Brzezinski and Nelson, 1989]. However, the average $\Sigma \rho \mathrm{Si}$ for that period was $40 \%$ lower than the production fluxes measured in April and June in the Gulf Stream. Despite the fact that the POMME study area is considered to be mesotrophic, with yet undepleted nutrients during spring bloom, Si production rates were extremely low and similar to the rates found in the oligotrophic gyres of the western Atlantic (Sargasso Sea and warm core eddies of the Gulf Stream), which are regions considered to encounter severe $\mathrm{Si}$ limitation throughout the year [Brzezinski and Nelson, 1996].

[42] The particulate silica export fluxes $\left(B \mathrm{Si}_{\exp }\right.$ flux $)$ were compared to other studies also conducted in the North Atlantic at similar latitudes (Table 4). Very similar $B \mathrm{Si}_{\text {exp }}$ fluxes were obtained between the flux measured in drifting sediment traps deployed at each site at $400 \mathrm{~m}$ during the second legs and the average fluxes measured in moored sediment traps deployed over one year in the POMME study area [Mosseri et al., 2005]. In most cases, BSi fluxes were measured at different depths $(150-3000 \mathrm{~m})$, but it has been shown that the $B$ Si fluxes was conservative between the surface and deep traps in diverse oceanic systems, confirming the paradigm that diatoms are associated with rapid sedimentation events to depth [Ragueneau et al., 2000]. Thus we expect our $B \mathrm{Si}_{\text {exp }}$ fluxes to be comparable with other studies. The average $B \mathrm{Si}_{\exp }$ flux measured at $400 \mathrm{~m}$ during the POMME cruises in the spring $(0.122 \mathrm{mmol}$ Si m $\left.\mathrm{m}^{-2} \mathrm{~d}^{-1}\right)$ was very close to those found at the PAP site at $1000 \mathrm{~m}\left(0.160 \mathrm{mmol} \mathrm{m} \mathrm{m}^{-2} \mathrm{~d}^{-1}\right)$, north of our study area [Lampitt et al., 2001]. The spring fluxes are also comparable to the annual average flux at the BATS site in the

Table 4. Comparative Table of Si Export Fluxes for the Entire POMME Area and Other Systems of the North Atlantic Between $150 \mathrm{~m}$ and $3000 \mathrm{~m}$ Depth

\begin{tabular}{|c|c|c|c|c|c|c|c|}
\hline \multirow[b]{2}{*}{ North Atlantic } & \multirow[b]{2}{*}{ Latitude, ${ }^{\circ} \mathrm{N}$} & \multicolumn{5}{|c|}{$B$ Si Flux, mmol m ${ }^{-2} \mathrm{~d}^{-1}$} & \multirow[b]{2}{*}{ References } \\
\hline & & $150 \mathrm{~m}$ & $200 \mathrm{~m}$ & $400 \mathrm{~m}$ & $1000 \mathrm{~m}$ & $3000 \mathrm{~m}$ & \\
\hline POMME 1 & $40-43.5$ & & 0.011 & 0.034 & & & \\
\hline POMME 2 & $40-43.5$ & & 0.189 & 0.122 & & & this study \\
\hline POMME 3 & $40-43.5$ & & 0.003 & 0.002 & & & \\
\hline POMME & $40-43.5$ & & & $0.039-0.147$ & $0.090-0.111$ & & Mosseri et al. [2005] \\
\hline PAP & 48.8 & & & & 0.160 & 0.235 & Lampitt et al. [2001] \\
\hline PAP & 48.8 & & & & & 0.139 & Ragueneau et al. [2001] \\
\hline PAP & 48.8 & & & & & 0.096 & \\
\hline NABE prebloom & 47.3 & & & & 0.024 & 0.005 & \\
\hline NABE bloom & 47.3 & & & & 0.117 & 0.018 & Honjo and Manganini [1993] \\
\hline NABE postbloom & 47.3 & & & & 0.028 & 0.011 & \\
\hline JGOFS/BOFS & 47.5 & & & & & 0.186 & Newton et al. [1994] \\
\hline BATS (Sargasso) & 31.5 & 0.130 & 0.113 & 0.085 & & 0.052 & Brzezinski and Nelson [1995] \\
\hline
\end{tabular}



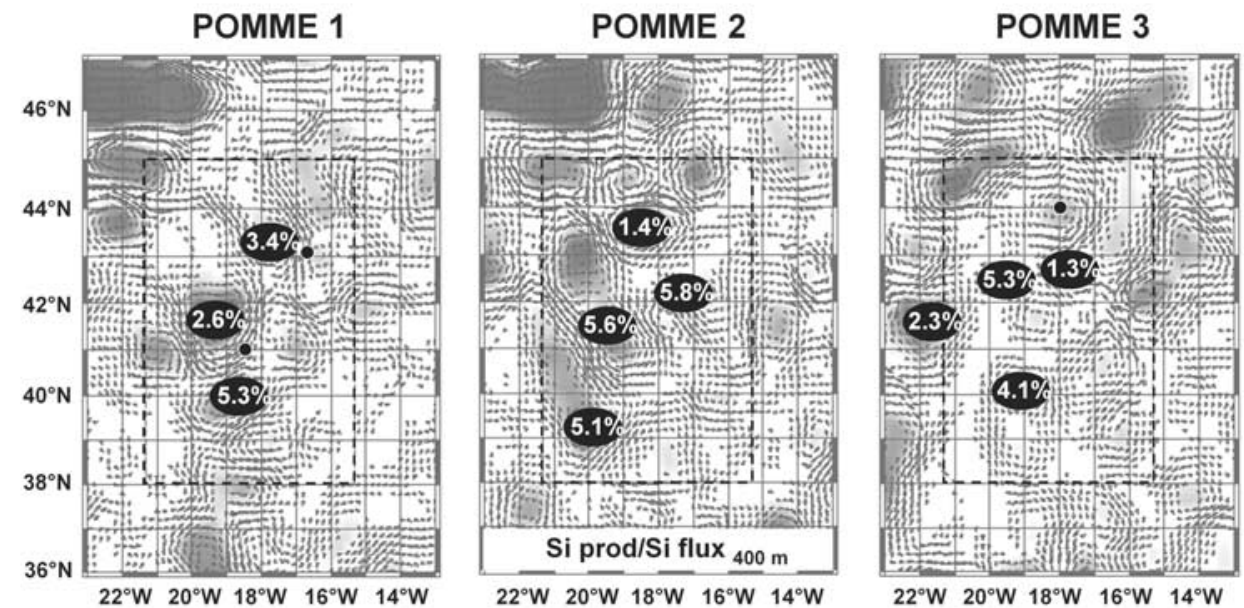

Figure 14. Percentage of the integrated Si production flux $(\Sigma \rho \mathrm{Si})$ in the surface layer exported to $400 \mathrm{~m}$ depth.

Sargasso Sea [Newton et al., 1994; Brzezinski and Nelson, 1995] and similar to the fluxes observed in the bloom period during NABE [Honjo and Manganini, 1993]. The fluxes reported for the PAP, BATS and BOFS study sites are however annual average fluxes, and may thus be considered higher than the $B \mathrm{Si}_{\exp }$ fluxes observed in our study area, where fluxes were only elevated during the productive period, and very low during both winter and late summer. Similarly, during NABE, fluxes recorded during the nonproductive period were much lower than the annual average at the PAP and BATS sites. The highest $B \mathrm{Si}_{\text {exp }}$ flux measured for the North Atlantic was recorded at $3000 \mathrm{~m}$ at the PAP site $\left(0.235 \mathrm{mmol} \mathrm{Si} \mathrm{m} \mathrm{m}^{-2} \mathrm{~d}^{-1}\right)$, which appears to be the site of important diatom sedimentation events. The differences in $B \mathrm{Si}_{\text {exp }}$ fluxes between PAP and POMME can be explained by the lesser intensity of the spring diatom bloom south of $45^{\circ} \mathrm{N}$. SeaWiFS satellite images indicate that the POMME study area was located south of the maximal spring bloom extension, situated between $44^{\circ}$ and $48^{\circ} \mathrm{N}$ (X. Pfeuty and M. Lévy, LODYC, personal communication, 2002). The north-south variability is thus important over a few degrees of latitude and diatom abundance appears to increase northward, with the increasing silicic acid availability. Koeve et al. [2002] also documented higher BSi concentrations at $47^{\circ} \mathrm{N}$ during spring, with values ranging between 74 and $258 \mathrm{mmol} \mathrm{m}^{-2}$ compared to $31 \pm 21 \mathrm{mmol} \mathrm{m}^{-2}$ measured during $\mathrm{P} 2$ at $40^{\circ}-43.5^{\circ} \mathrm{N}$.

[43] The percentage of biogenic silica produced in the surface layer and exported to $400 \mathrm{~m}$ was calculated $\left(\sum \rho \mathrm{Si} /\right.$ $\left.B \mathrm{Si}_{\text {exp400 }}\right)$ and reported for each site in Figure 14 . The percentage of $\mathrm{Si}$ exported to depth was higher during spring, with an average of $4.5 \%$ for all sites and was slightly lower during winter $(3.8 \%)$ and late summer $(3.2 \%)$. However, the fraction of exported biogenic silica did not vary significantly between the different season $(P>0.001$, t-test $)$ and the intrasite variability during each cruise was higher than the seasonal variability. The fraction of $\mathrm{Si}$ exported was less important in the A1 eddy despite the highest Si biomass and uptake rates observed. This may indicate either a more efficient recycling of the siliceous compartment in the surface layer or lateral advection processes as was suggested for the annual $B \mathrm{Si}_{\text {exp }}$ flux at the northern site by Mosseri et al. [2005]. The fraction of Si exported to depth during the POMME cruises remains very low compared to the global average of 50\% [Tréguer et al., 1995] and to the average for the Southern Ocean of 40\% [Ragueneau et al., 2002] but is close to the values of $10 \%$ measured in the oligotrophic Equatorial Pacific [Blain et al., 1999].

\subsubsection{Annual Si Production and Export Budgets}

[44] The average daily Si production and export rates were extrapolated to a yearly average over the POMME study area following the calculation described by Fernández et al. [2005]. On the basis of the nitrate stock, these authors estimated the length of the winter season to 49 days, the spring season to 59 days, and the rest of the year (257 days) was considered representative of the oligotrophic season. With a surface area for the POMME domain of $375000 \mathrm{~km}^{2}$, the annual Si fluxes was extrapolated to $9.8 \times 10^{9} \mathrm{~mol}$ Si $\mathrm{yr}^{-1}$ while the export fluxes at $400 \mathrm{~m}$ was estimated at $2.9 \times 10^{8} \mathrm{~mol} \mathrm{Si} \mathrm{yr}^{-1}$. Thus a yearly average of $3 \%$ of the $\mathrm{Si}$ produced in the surface layer is exported at $400 \mathrm{~m}$ between $40^{\circ}$ and $43.5^{\circ} \mathrm{N}$ in the North Atlantic.

\section{Conclusion}

[45] The results of the POMME cruises indicated an important seasonal variability of the siliceous compartment in the North Atlantic together with a spatial variability following a south-north gradient in parallel to the increasing stock of nutrients. The variability that could have been induced by the mesoscale hydrological features (anticyclonic and cyclonic eddies) was not apparent on particulate matter distribution and seemed masked by the south-north productivity gradient.

[46] In March, Chl $a$ stocks were already elevated and equal to or slightly superior to the pigment values observed during April, indicating an early start of the spring bloom occurring before the complete stratification of the surface layer. Diatoms abundance was overall minor and their contribution to primary production was estimated to be $<25 \%$ in the winter and $<4 \%$ in the late summer. The low contribution of diatoms to the early bloom was attributed to 
Si limitation over the entire study area. The dissolved Si:N ratio in the surface layer indicated a deficit of Si relative to $\mathrm{N}$, and the elevated $K_{S}$ Si values $(1.77$ to $5.92 \mu \mathrm{M})$ suggested that diatoms $\mathrm{Si}$ uptake rates were limited by silicic acid availability in the winter. In situ specific $\mathrm{Si}$ uptake rates ( $V \mathrm{Si}$ ) were limited to between 22 to $65 \%$ of their potential maximum uptake rates $\left(V_{\max }\right)$.

[47] During spring, diatoms contribution to primary production increased northward, in parallel to the increasing silicic acid stock, ranging from $10 \%$ in the southern A2 eddy up to $100 \%$ in the northern A1 eddy, where a PseudoNitzschia bloom was observed. Si uptake rates remained extremely low, except in A1, and seemed again limited by silicic availability. $\mathrm{K}_{\mathrm{S}} \mathrm{Si}$ values were lower $(0.72-$ $1.26 \mu \mathrm{M})$, reflecting a better adaptation of diatoms to decreasing concentrations over the course of the spring bloom, but $V \mathrm{Si}$ were still limited from 11 to $46 \%$ of their $V_{\max }$. In the southern part of the study area, an important drawdown of nitrate was likely to induce a simultaneous limitation of diatoms growth together with $\mathrm{Si}$. In the late summer, nutrient depletion of the surface layer resulted in a strong decrease of the siliceous component, Chl $a$ stocks and primary production, which was then dominated by the picophytoplanktonic fraction.

[48] The Si production budgets derived from in situ measurements were extremely low at all seasons (0.04$11.20 \mathrm{mmol} \mathrm{Si} \mathrm{m} \mathrm{m}^{-2} \mathrm{~d}^{-1}$ ) and closer to those established for other open ocean oligotrophic regimes such as the Sargasso Sea and the Gulf Stream rather than to those reported for productive areas. Several studies have already evidenced the poor uptake kinetic efficiency of diatoms in the North Atlantic and it has been hypothesized that the spring diatom bloom encounters chronic Si limitation [Brzezinski and Nelson, 1996; Brown et al., 2003]. The results of the POMME cruises tend to confirm these precedent studies, but simultaneous $\mathrm{Si}$ and $\mathrm{N}$ limitation were also likely to occur during spring, while nitrate depletion probably terminated the diatom bloom at the end of summer. Shipboard enrichment experiments described in a companion paper [Blain et al., 2005] also indicated that Fe may be limiting in this region.

[49] $\mathrm{Si}$ export fluxes to depth during the productive period were comparable to those measured in the same area on previous studies (PAP, NABE) but the average flux of the three seasons remained inferior to the annual fluxes measured between $47^{\circ}$ and $48^{\circ} \mathrm{N}$, where diatoms abundance was more important. The percentage of $\mathrm{Si}$ produced exported to $400 \mathrm{~m}$ varied between 1 and $6 \%$ over the POMME region and the intrasite variability was higher than the seasonal variability. Overall, Si export fluxes were very low compared to the global average of $50 \%$ for the open ocean.

[50] Acknowledgments. The authors would like to thank the captains and crews of the R/V L'Atalante and R/V Thalassa (IFREMER) for their invaluable help at sea during all POMME cruises. This work was supported by the French JGOFS program PROOF (PROcessus biogéochimiques dans l'Océan et Flux) and PATOM (Programme Atmosphère et Océan Multi-Echelles of CNRS/INSU).

\section{References}

Assenbaum, M., and G. Reverdin (2005), Near real-time analyses of the mesoscale circulation during the POMME experiment, Deep Sea Res. Part $I$, in press.
Berger, W. H., and G. Wefer (1990), Export production: Seasonality and intermittency, and paleoceanographic implications, Palaeoceanogr. Palaeoclimatol. Palaeoecol., 89, 245-254.

Blain, S., P. Tréguer, and M. Rodier (1999), Stocks and fluxes of biogenic silica in the western oligotrophic equatorial Pacific, J. Geophys. Res., 104, 3357-3367.

Blain, S., C. Guieu, H. Claustre, K. Leblanc, T. Moutin, B. Quéguiner, and G. Sarthou (2005), Availability of iron for phytoplankton in the northeast Atlantic Ocean, Limnol. Oceanogr., 49, 2095-2104.

Brown, L., R. Sanders, G. Savidge, and C. H. Lucas (2003), The uptake of silica during spring bloom in the northeast Atlantic Ocean, Limnol. Oceanogr., 48, 1831-1845.

Brzezinski, M. A. (1985), The Si:C:N ratio of marine diatoms: Interspecific variability and the effect of some environmental variables, J. Phycol., 21, $347-357$.

Brzezinski, M. A., and C. A. Kosman (1997), Silica production in the Sargasso Sea during spring 1989, Mar. Ecol. Prog. Ser., 142, 39-45.

Brzezinski, M. A., and D. M. Nelson (1986), A solvent extraction method for the colorimetric determination of nanomolar concentrations of silicic acid in seawater, Mar. Chem., 19, 139-151.

Brzezinski, M. A., and D. M. Nelson (1989), Seasonal changes in the silicon cycle within a Gulf Stream warm-core ring, Deep Sea Res., Part I, 36, 1009-1030.

Brzezinski, M. A., and D. M. Nelson (1995), The annual silica cycle in the Sargasso Sea near Bermuda, Deep Sea Res., Part I, 42, 1215-1237.

Brzezinski, M. A., and D. M. Nelson (1996), Chronic substrate limitation of silicic acid uptake rates in the western Sargasso Sea, Deep Sea Res., Part II, 43, 437-453.

Brzezinski, M. A., T. A. Villareal, and F. Lipschultz (1998), Silica production and the contribution of diatoms to new and primary production in the central North Pacific, Mar. Ecol. Prog. Ser., 167, 89-104.

Bury, S. J., P. W. Boyd, T. Preston, G. Savidge, and N. J. P. Owens (2001), Size-fractionated primary production and nitrogen uptake during a North Atlantic phytoplankton bloom: Implications for carbon export estimates, Deep Sea Res., Part I, 48, 689-720.

Caniaux, G., A. Brut, D. Bourras, H. Giordani, A. Paci, L. Prieur, and G. Reverdin (2005a), A 1 year sea surface heat budget in the northeastern Atlantic basin during the POMME experiment: 1. Flux estimates, J. Geophys. Res., 110, C07S02, doi:10.1029/2004JC002596.

Caniaux, G., S. Belamari, H. Giordani, A. Paci, L. Prieur, and G. Reverdin (2005b), A 1 year sea surface heat budget in the northeastern Atlantic basin during the POMME experiment: 2. Flux optimization, J. Geophys. Res., 110, C07S03, doi:10.1029/2004JC002695.

Claustre, H., et al. (2004), An intercomparison of HPLC phytoplankton pigment methods using in situ samples: Application to remote sensing and database activities, Mar. Chem., 85, 41-61.

Del Amo, Y., O. Le Pape, P. Tréguer, B. Quéguiner, A. Ménesguen, and A. Aminot (1997), Impacts of high-nitrate freshwater inputs on microtidal ecosystems. I. Seasonal evolution of nutrient limitation for the diatom-dominated phytoplankton of the Bay of Brest (France), Mar. Ecol. Prog. Ser., 161, 213-224.

Esaias, W. E., G. C. Feldman, C. R. McClain, and J. A. Elrod (1986), Monthly satellite-derived phytoplankton pigment distribution for the North Atlantic Ocean basin, Eos Trans. AGU, 67(44), 835-837.

Fernández, I. C., P. Raimbault, G. Caniaux, N. Garcia, and P. Rimmelin (2005), Influence of mesoscale eddies on nitrate distribution during the POMME program in the northeast Atlantic Ocean, J. Mar. Syst., 55, $155-175$.

Franck, V. M., K. W. Bruland, D. A. Hutchins, and M. A. Brzezinski (2003), Iron and zinc effects on silicic acid and nitrate uptake kinetics in three high-nutrient, low-chlorophyll (HNCL) regions, Mar. Ecol. Prog. Ser. $252,15-33$.

Giordani, H., G. Caniaux, L. Prieur, A. Paci, and S. Giraud (2005), A 1 year mesoscale simulation in the northeast Atlantic: Mixed layer heat and detrainment budgets during the POMME experiment, J. Geophys. Res., doi:10.1029/2004JC002765, in press.

Healey, F. P. (1980), Slope of the Monod equation as an indicator of advantage in nutrient competition, Microb. Ecol., 5, 281-286.

Honjo, S., and S. J. Manganini (1993), Annual biogenic particle fluxes to the interior of the North Atlantic Ocean studied at $34^{\circ} \mathrm{N} 21^{\circ} \mathrm{W}$ and $48^{\circ} \mathrm{N}$ $21^{\circ} \mathrm{W}$, Deep Sea Res., Part II, 40, 587-607.

Karrasch, B., H. G. Hoppe, S. Ullrich, and S. Podewski (1996), The role of mesoscale hydrography on microbial dynamics in the northeast Atlantic: Results of a spring bloom experiment, J. Mar. Res., 54, 99-122.

Koeve, W., F. Pollehne, A. Oschlies, and B. Zeitzschel (2002), Storminduced convective export of organic matter during spring in the northeast Atlantic Ocean, Deep Sea Res., Part I, 49, 1431-1444.

Lampitt, R. S. (1985), Evidence for the seasonal deposition of detritus to the deep-sea floor and its subsequent resuspension, Deep Sea Res., Part I, 32, 885-897. 
Lampitt, R. S., and A. N. Antia (1997), Particle flux in deep seas: Regional characteristics and temporal variability, Deep Sea Res., Part I, 44, 1377 1403

Lampitt, R. S., B. J. Bett, K. Kiriakikoulakis, E. E. Popova, O. Ragueneau, A. Vangriesheim, and G. A. Wolff (2001), Material supply to the abyssal seafloor in the northeast Atlantic, Prog. Oceanogr., 50, 27-63.

Le Cann, B., M. Assenbaum, C.-C. Gascard, and G. Reverdin (2005), Observed mean and mesoscale upper ocean circulations in the midlatitude northeast Atlantic during the POMME experiment (September 2000 2001), J. Geophys. Res., 110, C07S05, doi:10.1029/2004JC002768.

Lévy, M., Y. Lehahn, J.-M. André, L. Mémery, H. Loisel, and E. Heifetz (2005), Production regimes in the northeast Atlantic: A study based on Sea-viewing Wide Field-of-view Sensor chlorophyll and ocean general circulation model mixed layer depth, J. Geophys. Res., doi:10.1029/ 2004JC002771, in press.

Leynaert, A. (1993), La production de la Silice Biogenique dans l'Ocean: De la Mer de Weddell a l'Ocean Antarctique, Ph.D. thesis, 100 pp., Univ. Pierre et Marie Curie, Paris.

Lochte, K., H. E. Ducklow, M. J. R. Fasham, and C. Stienens (1993), Plankton succession and carbon cycling at $47^{\circ} \mathrm{N} 20^{\circ} \mathrm{W}$ during the JGOFS North Atlantic Bloom Experiment, Deep Sea Res., Part II, 40, 91-114.

Longhurst, A., S. Sathyendranath, T. Platt, and C. Caverhill (1995), An estimate of global primary production in the ocean from satellite radiometer data, J. Plankton Res., 17, 1245-1271.

Louanchi, F., and R. G. Najjar (2001), Annual cycles of nutrients and oxygen in the upper layers of the North Atlantic Ocean, Deep Sea Res., Part II, 48, 2155-2171.

Martin-Jézéquel, V., M. Hildebrand, and M. A. Brzezinski (2000), Silicon metabolism in diatoms: Implications for growth, J. Phycol., 36, $821-$ 840.

Mémery, L., G. Reverdin, J. Paillet, and A. Oschlies (2005), Introduction to the POMME special section: Thermocline ventilation and biogeochemical tracer distribution in the northeast Atlantic Ocean and impact of mesoscale dynamics, J. Geophys. Res., doi:10.1029/2005JC002976, in press.

Morel, A., and J. F. Berthon (1989), Surface pigments, algal biomass profiles, and potential production of the euphotic layer: Relationships reinvestigated in view of remote-sensing applications, Limnol. Oceanogr. 34, 1545-1562.

Mosseri, J., B. Quéguiner, P. Rimmelin, N. Leblond, and C. Guieu (2005), Sea fluxes in the northeast Atlantic frontal zone of Mode Water formation $\left(38^{\circ}-45^{\circ} \mathrm{N}, 16^{\circ}-22^{\circ} \mathrm{W}\right)$ in 2001-2002, J. Geophys. Res., 110, C07S19, doi:10.1029/2004JC002615.

Moutin, T., and P. Raimbault (2002), Primary production, carbon export and nutrients availability in western and eastern Mediterranean Sea in early summer 1996, J. Mar. Syst., 33-34, 273-288.

Nelson, M. D., and Q. Dortch (1996), Silicic acid depletion and silicon limitation in the plume of the Mississippi River: Evidence from kinetic studies in spring and summer, Mar. Ecol. Prog. Ser., 136, 163-178.

Nelson, D. M., and J. J. Goering (1978), Assimilation of silicic acid by phytoplankton in the Baja California and northwest Africa upwelling systems, Limnol. Oceanogr., 23, 508-517.

Nelson, D. M., and P. Tréguer (1992), Role of silicon as a limiting nutrient to Antarctic diatoms: Evidence from kinetic studies in the Ross Sea ice-edge zone, Mar. Ecol. Prog. Ser., 80, 255-264.

Nelson, D. M., J. J. Goering, S. S. Kilham, and R. R. L. Guillard (1976), Kinetics of silicic acid uptake and rates of silica dissolution in the marine diatom Thalassiosira pseudonana, J. Phycol., 12, 246-252.

Nelson, D. M., W. O. J. Smith, R. D. Muench, L. I. Gordon, C. W. Sullivan, and D. M. Husby (1989), Particulate matter and nutrient distributions in the ice-edge zone of the Weddell Sea: Relationship to hydrography during late summer, Deep Sea Res., Part A, 36, 191-209.

Newton, P. P., R. S. Lampitt, T. D. Jickells, P. King, and C. Boutle (1994), Temporal and spatial variability of biogenic particle fluxes during the JGOFS northeast Atlantic process studies at $47^{\circ} \mathrm{N}, 20^{\circ} \mathrm{W}$, Deep Sea Res., Part I, 41, 1617-1642.

Paasche, E. (1973), Silicon and the ecology of marine plankton diatoms. I. Thalassiosira pseudonana (Cyclotella nana) grown in a chemostat with silicate as the limiting nutrient, Mar. Biol., 19, 117-126.

Paasche, E. (1980), Silicon content of five marine plankton diatom species measured with a rapid filter method, Limnol. Oceanogr, 25, 474-480.

Passow, U., and R. Peinert (1993), The role of plankton in particle flux: Two case studies from the northeast Atlantic, Deep Sea Res., Part II, 40, $573-585$.

Ragueneau, O., A. Leynaert, P. Tréguer, D. M. Nelson, G. Fischer, D. J. DeMaster, C. Heinze, R. François, and R. F. Anderson (1997), OPALEO (OPAL as PALEO-productivity proxy), Synthesis and perspectives, in
Final Report From the First 2 International Workshop (Brest 96, Corvallis 97), edited by $\mathrm{O}$. Ragueneau, A. Leynaert, and P. Tréguer, Brest, France.

Ragueneau, O., et al. (2000), A review of the Si cycle in the modern ocean: Recent progress and missing gaps in the application of biogenic opal as a paleoproductivity proxy, Global Planet. Change, 26, 317-365.

Ragueneau, O., et al. (2001), The benthic silica cycle in the northeast Atlantic: Annual mass balance, seasonality, and importance of non-steady state processes for the early diagenesis of biogenic opal and deep-sea sediments, Prog. Oceanogr, 50, 171-200.

Ragueneau, O., N. Dittert, P. Pondaven, P. Tréguer, and L. Corrin (2002), $\mathrm{Si} / \mathrm{C}$ decoupling in the world ocean: Is the Southern Ocean different? Deep Sea Res., Part II, 49, 3127-3154.

Redfield, A. C., B. H. Ketchum, and F. A. Richards (1963), The influence of organisms on the composition of sea water, in The Sea, Ideas and Observations on Progress in the Study of the Seas, edited by M. N. Hill, pp. 26-77, Wiley-Interscience, Hoboken, N. J.

Reverdin, G., M. Assenbaum, and L. Prieur (2005), The Eastern North Atlantic Mode Waters during POMME (September 2000-2001), J. Geophys. Res., doi:10.1029/2004JC002613, in press.

Savidge, G., P. Boyd, A. Pomroy, D. Harbour, and I. Joint (1995), Phytoplankton production and biomass estimates in the northeast Atlantic Ocean, May-June 1990, Deep Sea Res., Part I, 42, 599-617.

Siegel, D. A., S. C. Doney, and J. A. Yoder (2001), The North Atlantic spring phytoplankton bloom and Sverdrup's critical depth hypothesis, Science, 296, 730-733.

Sieracki, M. E., P. G. Verity, and D. K. Stoecker (1993), Plankton community response to sequential silicate and nitrate depletion during the 1989 North Atlantic spring bloom, Deep Sea Res., Part II, 40, 213-225.

Smetacek, V. S. (1985), Role of sinking in diatom life-history cycles: Ecological, evolutionary and geological significance, Mar. Biol., 84, 239251

Stramska, M., T. D. Dickey, A. Plueddemann, A. Weller, C. Langdon, and J. Marra (1995), Bio-optical variability associated with phytoplankton dynamics in the North Atlantic Ocean during spring and summer of 1991, J. Geophys. Res., 100, 6621-6632.

Sullivan, C. W., and B. E. Volcani (1981), Silicon in the cellular metabolism of diatoms, in Silicon and Siliceous Structures in Biological Systems, edited by T. L. Simpson and B. E. Volcani, pp. 15-42, Springer, New York.

Sverdrup, H. U. (1953), On conditions for the vernal blooming of phytoplankton, J. Cons. Int. Explor. Mer., 18, 287-295.

Takahashi, T., et al. (2002), Global sea-air $\mathrm{CO}_{2}$ flux based on climatological surface ocean $\mathrm{pCO}_{2}$, and seasonal biological and temperature effects, Deep Sea Res., Part II, 49, 1601-1622.

Taylor, A. H., D. S. Harbour, R. P. Harris, P. H. Burkill, and E. S. Edwards (1993), Seasonal succession in the pelagic ecosystem of the North Atlantic and the utilization of nitrogen, J. Plankton Res., 15, 875-891.

Tréguer, P., and P. Le Corre (1975), Manuel d'analyses des sels nutritifs dans l'eau de mer: Utilisation de l'Auto-Analyzer II Technicon, 2nd ed., 110 pp., Lab. de Chim. Mar. Univ. de Bretagne Occident., Brest, France. Tréguer, P., L. Lindner, A. J. van Bennekom, A. Leynaert, M. Panouse, and G. Jacques (1991), Production of biogenic silica in the Weddell-Scotia Seas measured with ${ }^{32} \mathrm{Si}$, Limnol. Oceanogr., 36, 1217-1227.

Tréguer, P., D. M. Nelson, A. J. van Bennekom, D. J. Demaster, B. Quéguiner, and A. Leynaert (1995), The silica budget of the world ocean: A re-estimate, Science, 268, 375-379.

van Aken, H. M. (2001), The hydrography of the mid-latitude northeast Atlantic Ocean, part III: The subducted thermocline water mass, Deep Sea Res., Part I, 48, 237-267.

K. Leblanc, College of Marine Studies, 700 Pilottown Road, Lewes, DE 19958, USA. (leblanc@udel.edu)

A. Leynaert, Laboratoire "Flux de matière et réponse du vivant," Institut Universitaire Européen de la Mer, Technopôle Brest-Iroise, place N. Copernic, F-29280 Plouzané, France. (aude.leynaert@univ-brest.fr)

C. Fernandez I., T. Moutin, P. Raimbault, P. Rimmelin, and B. Quéguiner, Laboratoire d'Océanographie et de Biogéochimie, UMR 6535, CNRS, Université de la Méditerranée, Campus de Luminy, Case 901, F-13288 Marseille Cedex 09, France. (fernandez@com.univ-mrs.fr; moutin@ com.univ-mrs.fr; raimbaul@com.univ-mrs.fr; rimmelin@com.univ-mrs.fr; bernard.queguiner@com.univ-mrs.fr)

J. Ras, Laboratoire d'Océanographie de Villefranche, CNRS-INSU et Université Pierre et Marie Curie, B.P. 28, F-06238 Villefranche-sur-mer, France. (claustre@ccrv.obs-vlfr.fr) 